\title{
Cenomanian transgression in the Basque-Cantabrian Basin (northern Spain) and associated faunal replacement
}

\author{
M.A. López-Horgue ${ }^{1}$, F.J. Poyato-Ariza², L. Cavin ${ }^{3}$, D.D. Bermúdez-Rochas ${ }^{4}$ \\ ${ }^{1}$ Estratigrafia eta Paleontologia, Zientzia eta Teknologia Fakultatea, University of the Basque Country UPV/EHU, Sarriena z/g, \\ 48940 Leioa, Basque Country, Spain \\ ${ }^{2}$ Unidad de Paleontología, Departamento de Biología, Universidad Autónoma de Madrid, Cantoblanco, 28049-Madrid, Spain \\ ${ }^{3}$ Department of Geology and Palaeontology, Muséum d'Histoire Naturelle, CP6434, 1211 Genève 6, Switzerland \\ ${ }^{4}$ Área de Didáctica de las CC. Experimentales, Facultad de Educación, Universidad de Cantabria, Avda. de los Castros s/n, \\ 39005-Santander, Spain
}

e-mail addresses: mikel.lopezhorgue@ehu.es (M.A.L.-H.., corresponding author); francisco.poyato@uam.es (F.J.P.-A.); Lionel.Cavin@ville-ge.ch (L.C.); david. bermudez@unican.es (D.D.B.-R.)

Received: 18 October 2013 / Accepted: 3 September 2014 / Available online: 30 October 2014

\begin{abstract}
The available data concerning the environmental changes and faunal replacements that occurred during the Cenomanian marine transgression in the North of Iberia are integrated and discussed on the basis of new evidence from the invertebrate and vertebrate fossil record. New stratigraphical data and the reassessment of known stratigraphic sections support the correlation of the Cenomanian carbonate-ramp successions from the Iberian margin to the centre of the Basque-Cantabrian Basin during a major transgressive episode. This new stratigraphical framework is the key to understand the changing oceanographic conditions in the area that resulted from a progressive inundation of the Iberian continental platform. This transgression seems to have triggered major faunal replacements in this particular geographic area, starting out around the Albian-Cenomanian transition. Ammonite faunal replacement led to a new radiation of this group that spread out rapidly until their new decline around the Cenomanian-Turonian boundary. A new record of Calycoceras (Newboldiceras) asiaticum spinosum and the first record of a Pachyrhizodontidae indet. (Actinopterygii, Teleostei, Crossognathiformes) from the Iberian Peninsula are reported here from the Cenomanian basal units of the major Late Cretaceous transgressive episode. The two new specimens come from the same level in an outer marine ramp succession near Amurrio, Basque Country, northern Spain, and are representatives of the Cenomanian faunal turnover. The new record of a pachyrhizodontoid fish from the Cretaceous of Iberia is an indication of the ichthyofaunal replacement in this part of the world. The relict fish faunas from the Early Cretaceous of the former island of Iberia were mostly formed by basal neopterygian taxa closely related to those of the marine Jurassic of other parts of Europe. During the Early-Late Cretaceous transition they were replaced by the teleostean-based new stock that constitutes the basis of the Late Cretaceous, Cenozoic, and Recent faunas.
\end{abstract}

Keywords: Cenomanian, Iberia, marine transgression, faunal replacement, Acanthoceratoidea, Pachyrhizodontidae

Resumen

Se integran y discuten los datos disponibles sobre los cambios ambientales y los reemplazamientos faunísticos que sucedieron en el norte de Iberia durante la transgresión del Cenomaniense, incluyéndose nuevas evidencias de los registros fósiles de invertebrados y vertebrados. Nuevos datos estratigráficos y la revisión de secciones estratigráficas conocidas proporcionan fundamentos para la correlación de las series de rampa carbonatada cenomanienses desde el margen ibérico hasta la zona central de la Cuenca Vasco-Cantábrica, desarrolladas durante un importante episodio transgresivo. Este nuevo esquema estratigráfico configura la base para entender las cambiantes condiciones oceanográficas en la zona de estudio, las cuales resultaron de una progresiva inundación del margen continental ibérico. Esta transgresión se vislumbra como factor determinante para reemplazamientos faunísticos en esta zona, que comenzaron durante el tránsito Albiense-Cenomaniense. Los cambios en las faunas de ammonites condujeron hacia una rápida radiación del grupo hasta un nuevo declive alrededor del tránsito Cenomaniense-Turoniense. Se describen aquí un nuevo registro de Calycoceras (Newboldiceras) asiaticum spinosum y el primer registro de Pachyrhizodontidae indet. (Actinopterigii, Teleostei, Crossognathiformes) de la Península Ibérica, provenientes de la parte basal 
del episodio transgresivo cenomaniense. Ambos son representativos del cambio faunístico y proceden del mismo nivel estratigráfico en una serie de rampa carbonatada externa cerca de Amurrio, País Vasco, España. Asimismo, este primer Pachyrhizodontoidei del Cretácico de Iberia indica un cambio importante en las faunas de teleósteos en esta parte del mundo. Las faunas relictas de peces del Cretácico inferior de la entonces isla de Iberia estaban básicamente compuestas por neopterigios basales directamente relacionados con los del Jurásico marino de otras partes de Europa. Durante la transición Cretácico Inferior-Cretácico Superior fueron paulatinamente reemplazados por nuevos grupos de teleósteos, los cuales constituyen la mayor parte de las formas del Cretácico Superior, del Cenozoico y actuales.

Palabras clave: Cenomaniense, Iberia, transgresión marina, reemplazamiento faunístico, Acanthoceratoidea, Pachyrhizodontidae

\section{Introduction}

Environmental changes and faunal replacement are highly complex processes, in which many factors of diverse origins are involved. As a consequence, any attempt to understand these phenomena requires complementary sedimentological, stratigraphical, and palaeontological evidence. The aim of this paper is to examine the palaeoenvironmental changes occurred during the marine transgression of the Cenomanian in the North of Iberia. New stratigraphic data are presented and discussed, together with a reassessment of previous data. New additions to the fossil record are integrated into the stratigraphy in order to understand the time and nature of the faunal replacement during the Early to Late Cretaceous transition in the North of Iberia; evolutionary implications are briefly discussed.

The Cenomanian stage is characterised by a major firstorder sea-level rise (Haq et al., 1987), which resulted in the flooding of continental areas and in the development of widespread shallow marine depositional settings. This new oceanographic scenario led to faunal turnovers in groups like ammonites (e. g., Wright et al., 1996) and teleostean fishes (e. g., Arratia, 2000). Studies on sequence stratigraphy from separated marine Cenomanian successions with a highresolution ammonite biostratigraphy have demonstrated that sea-level changes are globally synchronous and therefore eustatic in origin (Anglo-Paris basin, Robaszynski et al., 1998; India and northwest Europe, Gale et al., 2002; southwest Morocco, Kuhnt et al., 2009). Therefore, the signature of global oceanographic changes could be recognized in the sedimentary and palaeontological record of separated sedimentary basins. Our study area is placed in the northern Iberian margin of the Basque-Cantabrian Basin (BCB), an area located between Africa and Europe. Cenomanian sedimentation in the $\mathrm{BCB}$ occurred on tectonic blocks with differential subsidence postdating a more active tectonic subsidence phase during the Albian (e. g., García-Mondéjar et al., 2004; Floquet, 2004). This led to the development of widespread carbonate ramps with differential stratigraphic records. We present here new faunal data and an updated biostratigraphy-based correlation of shallow-to-deep marine successions of the latest Albian-Cenomanian in the middle part of the Basque-Cantabrian Basin (e. g., Rodríguez-Lázaro et al., 1998; Gräfe and Wendler, 2003; Barroso-Barcenilla et al., 2011a, 2011b). This correlation has been the key framework to understand the onset of the great transgression that lasted until Santonian times. A remarkable specimen of a teleostean pachyrhizodontid fish and a new specimen of the ammonite Calycoceras (Newboldiceras) asiaticum spinosum (Kossmat, 1897) are reported from the same level in a carbonate ramp succession in Aiara, west of Amurrio (Araba province, Basque Country, Spain). The fossil fish specimen is the first report of the order Crossognathiformes from the Iberian Peninsula. The stratigraphy of the fish-bearing shallow marine carbonate succession is compiled and revised here in order to provide an accurate stratigraphical and palaeoecological context for the newly reported fauna.

\section{Material and methods}

\subsection{Field work}

Herein we provide new data from the latest Albian-Cenomanian succession of the Amurrio and Leioa areas (Fig. 1), consisting of the measurement of partial successions and their correlation to the succession of the Cidad-Puentedy area (Figs. 1-3). We have distinguished the main stratigraphic units in the Amurrio area following the nomenclature of Lotze (1960), and chosen two well outcropped stratigraphic markers for correlation. The stratigraphic markers are the base of a marl-limestone alternation (base of Lower Campillo beds, A in figs. 2 and 3) and the top of a calcarenite interval (basal Hijuela beds, B in figs. 2 and 3). These stratigraphic markers were the key for field and cartography-based correlation with the well dated Villasana Cenomanian succession (e. g., Wiedmann, 1979; Gräfe and Wendler, 2003) located west of Amurrio. The new ammonite data have permitted a re-assessment of the ammonite biostratigraphy in the study area. The integration of the biostratigraphical data from the mentioned areas has been the basis for the shallow-to-deep basin correlation (Fig. 3).

\subsection{Ammonites}

The new specimen of ammonite reported here occurred together with fragmentary undetermined inoceramids in fishbearing beds. It is an incomplete internal mould composed of marly limestone as the bearing sediment; this preservation and the lack of tractive sedimentary structures indicates that this specimen is autochthonous. It is deposited in the Museo de Ciencias Naturales de Álava / Arabako Natur Zientzien Museoa (repository MCNA 14392). 
Fig. 1.- Palaeogeographical map for the Cenomanian-Santonian of the Basque-Cantabrian Basin. Modified from Floquet (2004) with data from Wiedmann (1979), Gräfe (1996), and López-Horgue et al. (2010).

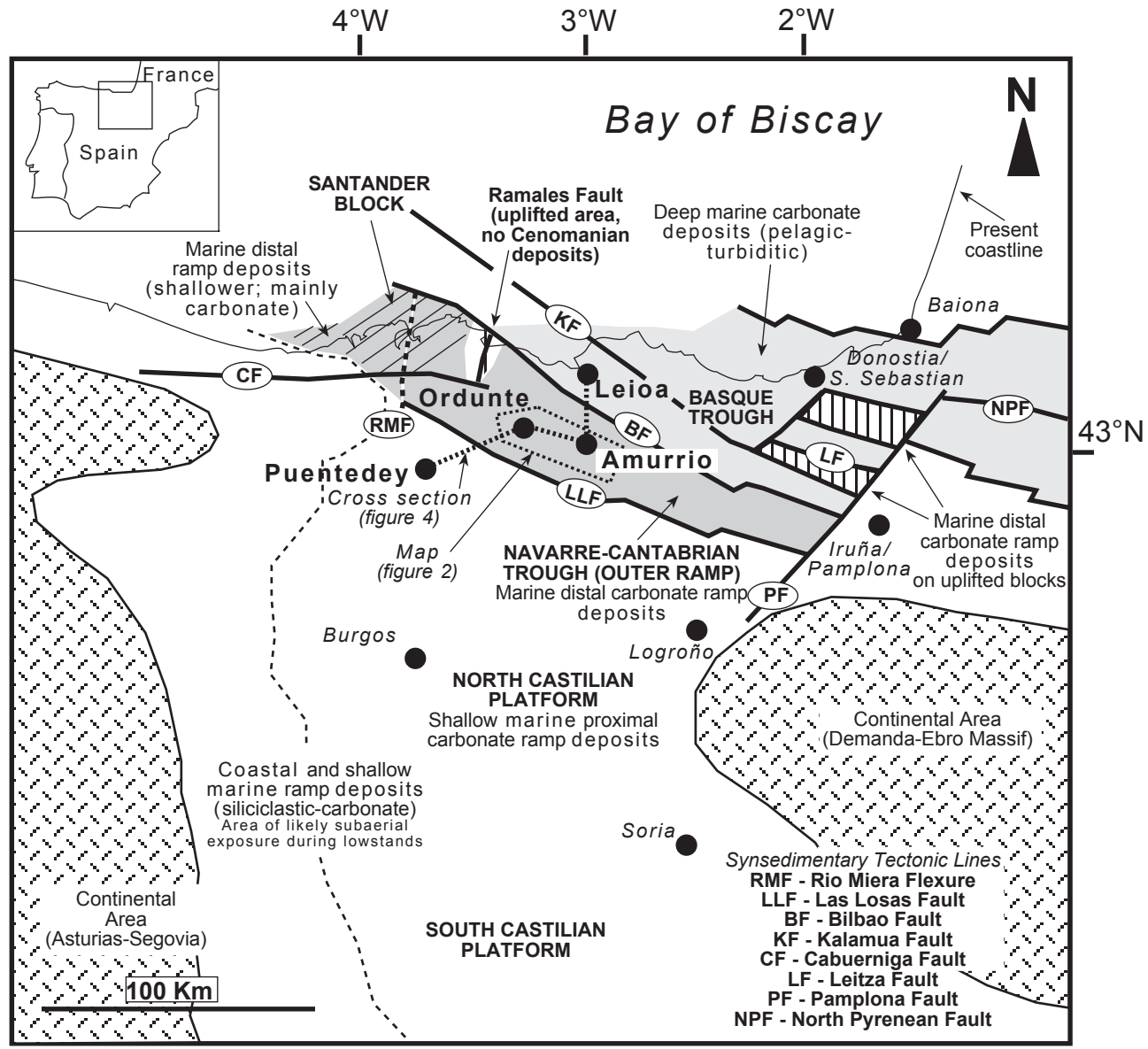

New occurrences of Late Albian ammonites near Amurrio (Ziorraga locality) and Ordunte (Balmaseda locality), and in the Leioa area (Ondiz locality) are currently under study and are here only considered to put the Albian-Cenomanian change in the ammonite associations into a proper context.

\subsection{Teleostei}

The fish specimen reported here is labelled Aztarna-1 in the collection of the Asociación Etnográfica Aztarna, located in Landako 8, Amurrio, Araba province, Basque Country, Spain. It was found some decades ago by Félix Murga (1929-2001; priest of Amurrio), in an excavation for a small reservoir in the Izoria locality, near Amurrio, but has never been studied or published. The specimen and its matrix were formerly covered with a thick glue coat. This coat, about 25 years old, was removed with ethanol and a thin brush, occasionally also with a thin surgical blade. After this process, it appeared that the matrix and, unfortunately, the specimen were treated with some heavily abrasive method prior to covering it with glue. This is one of the main reasons for its current poor preservation. In order to try to reveal as many anatomical details as possible, we took special care in photographing the specimen. However, only mechanic preparation, and especially acid treatment, may reveal additional, better preserved parts of the specimen; in particular, transfer preparation would be useful to show the right side, hidden in the matrix.

\section{Stratigraphy and geological setting}

\subsection{Upper Cretaceous stratigraphy}

The Upper Cretaceous carbonate succession cropping out near Amurrio (Araba province, Basque Country, Spain) is basically made up of sediments deposited in a large shallow marine carbonate ramp environment developing during a major transgressive episode in the Basque Cantabrian Basin (BCB) (e. g., Floquet, 2004). These large ramps were evolved at the southern margin of the BCB (i. e., the north Iberian passive margin) with marine facies reaching the Iberian basins in the Santonian peak transgression (e. g., Floquet, 2004). The onset of the Late Cretaceous transgression in the earliest Cenomanian occurred with the change of the subsidence style in the $\mathrm{BCB}$ from a phase of rifting subsidence (with important crustal thinning; Late Albian) to a phase of post-rift subsidence (less active fault-related subsidence and relative crustal cooling after a major phase of vulcanism during the Late Albian; e. g., García-Mondéjar et al., 2004). It finished with the onset of a major regressive episode in the Early to Middle Campanian (e. g., Floquet, 2004).

At the north Iberian margin, this Upper Cretaceous marine carbonate ramp is divided into three distinctive palaeogeographical areas from south to north (e. g., Feuillée, 1967; Lamolda, 1998; Floquet, 2004) (Fig. 1): 1. the Castilian Platform, with coastal to inner marine ramp environments; 2 . the 


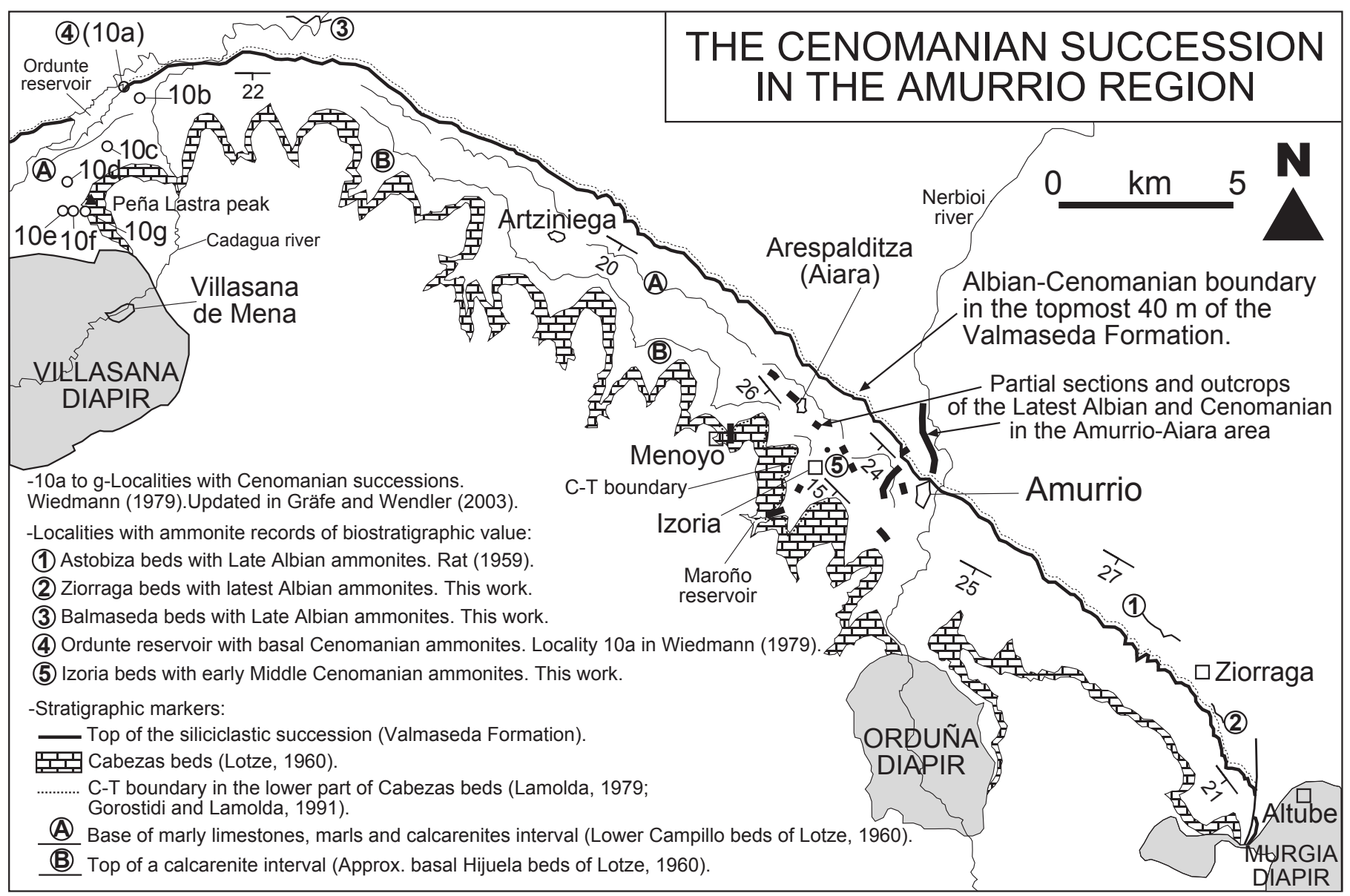

Fig. 2.- Cartography of the Cenomanian in the Amurrio Region, between Villasana de Mena, Amurrio, and Altube localities, with indication of partial sections and outcrops in Amurrio and Aiara localities, outcrops in the Ordunte-Villasana area, stratigraphic markers, and beds with ammonite and foraminifera occurrences.

Navarre-Cantabrian Trough, with outer marine ramp environments mainly under the storm wave base; and 3. the Basque Trough, with talus to deep marine environments. Hemipelagic to pelagic facies are widespread in the latter two areas. The uppermost Albian to Cenomanian and Lower Turonian succession in the Navarre-Cantabrian Trough (600-800 m thick) is divided into six sedimentary cycles (Gräfe, 1996; Gräfe and Wendler, 2003), and is interpreted as deposited in a distally steepened ramp (Gräfe and Wiedmann, 1993). During the Cenomanian, the Navarre-Cantabrian Trough is separated to the west from the North Cantabrian Basin (Santander Block) by the non-depositional structural high of the Ramales Fault (López-Horgue et al., 2010) (Fig. 1). In the North Cantabrian Basin, Wilmsem (1997) divided the 150-250 m thick Cenomanian succession into six depositional sequences, mainly influenced by the pulsatory nature of the Cenomanian transgression but bounded by two tectoevents at around the Albian-Cenomanian boundary and at the middle Late Cenomanian (Wiese and Wilmsen, 1999).

Floquet (2004) divided the uppermost Albian to Maastrichtian sediments of the BCB into six Transgressive-Regressive (T-R) main sequences. These can be divided into several minor T-R cycles representing ramp progradation phases.

\subsection{Biostratigraphy and regional correlation of the Cenomanian stage}

Upper Cretaceous sediments of the Basque-Cantabrian Basin bear abundant faunas of planktic foraminifera that traditionally have been used as biostratigraphical indices especially in outer ramp to deep marine facies (e. g., Rodríguez-Lázaro et al., 1998). In shallow marine facies, benthic foraminifera have been also used (e. g., Cherchi and Schroeder, 1998). Regional unconformities are common towards shallower facies associated with important hiatuses and stratigraphic condensation, so that biostratigraphical successions are necessarily incomplete. Early and Middle Cenomanian ammonites are practically absent in more proximal ramp areas of the Navarre-Cantabrian Trough and in the North Castilian Platform due to the diachronous character of the transgression (e. g., section of Hortezuelos, east of Burgos; Wiedmann, 1975). However, these cephalopods do occur in the outer ramp, while becoming almost absent in many stratigraphic intervals of the talus-to-deep marine facies. Accordingly, ammonites of the outer ramp areas with expanded successions and short-gap unconformities (such as the Amurrio area) are highly suitable for biostratigraphical 
analysis (e. g., southeastern part of the Navarre-Cantabrian Trough; Santamaría and López, 1996).

In this work we present a new proposal of regional correlation of the Cenomanian stage (Figs. 1-4) from inner ramp successions of the North Castilian Platform (Cidad-Puent- edey, Burgos province: Wiedmann, 1979; Floquet, 1989; Barroso-Barcenilla et al., 2011b) via outer ramp successions of the Amurrio and Villasana areas in the Navarre-Cantabrian Trough (Feuillé, 1967; Lamolda, 1979; Gorostidi and Lamolda, 1991; Rodríguez-Lázaro et al., 2003; Wiedmann,

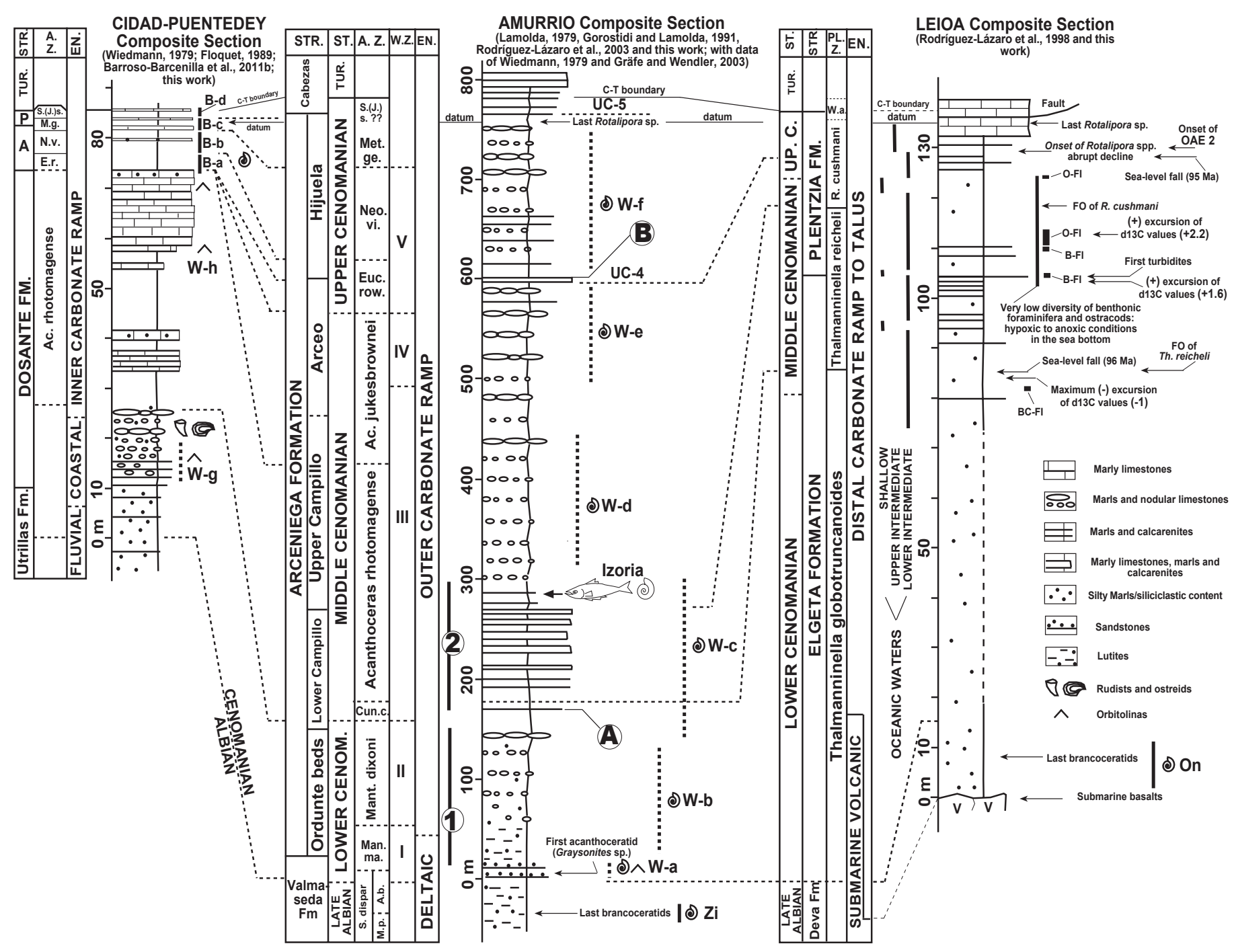

Fig. 3.- Correlation of the Cenomanian succession from the inner marine ramp area of Cidad-Puentedey (North Castilian Platform) via the outer marine ramp area of Amurrio (Navarre-Cantabrian Trough) to the deep marine Leioa area (Basque Trough). See Figs.1 and 2 for location. The composite sections are based on new data (this work) and on: lithostratigraphy from Lotze (1960), Wiedmann (1979) and Floquet (1989, 2004); ammonite occurrences and biozonation from Wiedmann (1979); new ammonite occurrences and biozonation for the Upper Cenomanian of the North Castilian Platform from Barroso-Barcenilla et al. (2009, 2011) and those revised in Gräfe (1996) and Gräfe and Wendler (2003); ammonite biozonation for the Upper Cretaceous of Europe from Kennedy (1984); planktic foraminifera occurrences and biozonation from Rodríguez-Lázaro et al. (1998), Lamolda (1979), Martínez et al. (1996) and Gräfe and Wendler (2003); calcareous nannofossil data from Gorostidi and Lamolda (1991); planktic foraminifera biozonation of Robaszynski and Caron (1995). Sedimentary unconformities come from Gräfe and Wendler (2003), contrasted to the eustatic sea level curve for the Cenomanian of Gale et al. (2002) and to data from the $\delta^{13} \mathrm{C}$ curve for the Cenomanian-Campanian of Jarvis et al. (2006). Key for ammonite biozones in ascending order: Mortoniceras (Durnovarites) perinflatum; Arrhaphoceras (Praeschloenbachia) briacensis; Mantelliceras mantelli; Mantelliceras dixoni; Cunningtoniceras cunningtoni; Acanthoceras rhotomagense; Acanthoceras jukesbrownei; Eucalycoceras rowei; Neolobites vibrayeanus; Metoicoceras geslinianum; Spathites (Jeanrogericeras) subconciliatus. W. a., Whiteinella archaeocretacea planktic foraminifera Zone. Other abbreviations: BC-FI, benthic calcitic-free interval; B-FI, benthic-free interval; O-FI, ostracod-free interval; FO, first occurrence; STR., lithostratigraphical units; ST., stages and substages; A. Z., ammonite zones; W. Z., ammonite zones of Wiedmann, 1979; PL. Z., planktic foraminifera zones; EN., sedimentary environment; A., Arceniega Formation; P., Puentedey Formation. Ammonite and orbitolinid occurrences: B-a to d, from Barroso-Barcenilla et al. (2011); W-a to h, from Wiedmann (1979); Zi, Ziorraga (Amurrio area), and On, Ondiz (Leioa area) (this work). UC-4 and UC-5 are unconformities following Gräfe (1994). Circled numbers refer to stratigraphic intervals represented in figure 4. Circled letters refer to selected stratigraphic markers (see fig. 2). See appendix 1 for details in ammonite and orbitolinid faunas. See text for more details. 
1979; Gräfe and Wiedmann, 1993; new data) to deep marine successions of the Basque Trough (Leioa, Biscay province: Rodriguez-Lázaro et al., 1998; new data). This correlation is based on:

1-biozonation with ammonites after reinterpretation of data of Wiedmann and Kauffman (1978) and Wiedmann (1979) for the coeval Villasana section, the new biostratigraphical proposal of Gräfe (1996), the updated biostratigraphy for the Villasana section (Gräfe and Wendler, 2003), the new biozonation for the Upper Cenomanian in the Puentedey area (Barroso-Barcenilla et al., 2009; Barroso-Barcenilla et al., 2011a, 2011b), a proposal of correlation to the European biozonation (Kennedy, 1984; Ogg et al., 2004), recent discoveries (Amurrio area, Balmaseda and Leioa, this paper), and comparison with biozones from southeastern areas of the Navarre-Cantabrian Trough (Estella-Lizarra area; Santamaría, 1992; López-Horgue et al., 1999) (Appendix 1);

2-biozonation with planktic foraminifera for the Amurrio and Villasana areas (Wiedmann, 1979; Lamolda, 1979; Martínez et al., 1996; Gräfe and Wendler, 2003), for the Leioa section (Rodríguez-Lázaro et al., 1998), and their correlation with ammonite zones after Robaszynski and Caron (1995);

3 -recognition of the main stratigraphic divisions of the Cenomanian distinguished in the Villasana area (Lotze, 1960; Wiedmann, 1979; Gräfe and Wendler, 2003) and their correlation in the field towards the Amurrio and Altube areas; 4-comparison with the eustatic sea level curve of Gale et al. (2002) and to the European $\delta^{13} \mathrm{C}$ record of Jarvis et al. (2006).

This correlation allows to track the thickness variations of the Cenomanian carbonate ramp sediments of the middle part of the Basque-Cantabrian Basin across three different palaeogeographical areas with distinctive sedimentation and subsidence patterns.

\section{Palaeoecology, bioevents and sedimentation}

The Cenomanian represents a time of abrupt change in the palaeoceanographic conditions in the $\mathrm{BCB}$, which determined turnovers in the marine faunal composition (e. g. , López-Horgue et al., 1999). A period of progressive transgression that culminates during the Santonian and the change of subsidence led to the development of large shallow marine areas (Fig. 1). Under these new conditions, sea-level falls led to: decrease of the depth of the marine environment, change in the characteristics of the water masses, a likely incursion of shallow marine waters, and condensation/erosion/no deposition in shallow areas. Sea-level falls were not large enough to produce subaerial exposures in these huge ramps, except for coastal areas to the south (see Fig. 1). Accordingly, sealevel rises led to: increase the water depth (if subsidence is $\geq 0$ ), likely incursion of deeper oceanic waters and sediment starvation in the deepest areas. Figure 4 shows a 2-D corre-

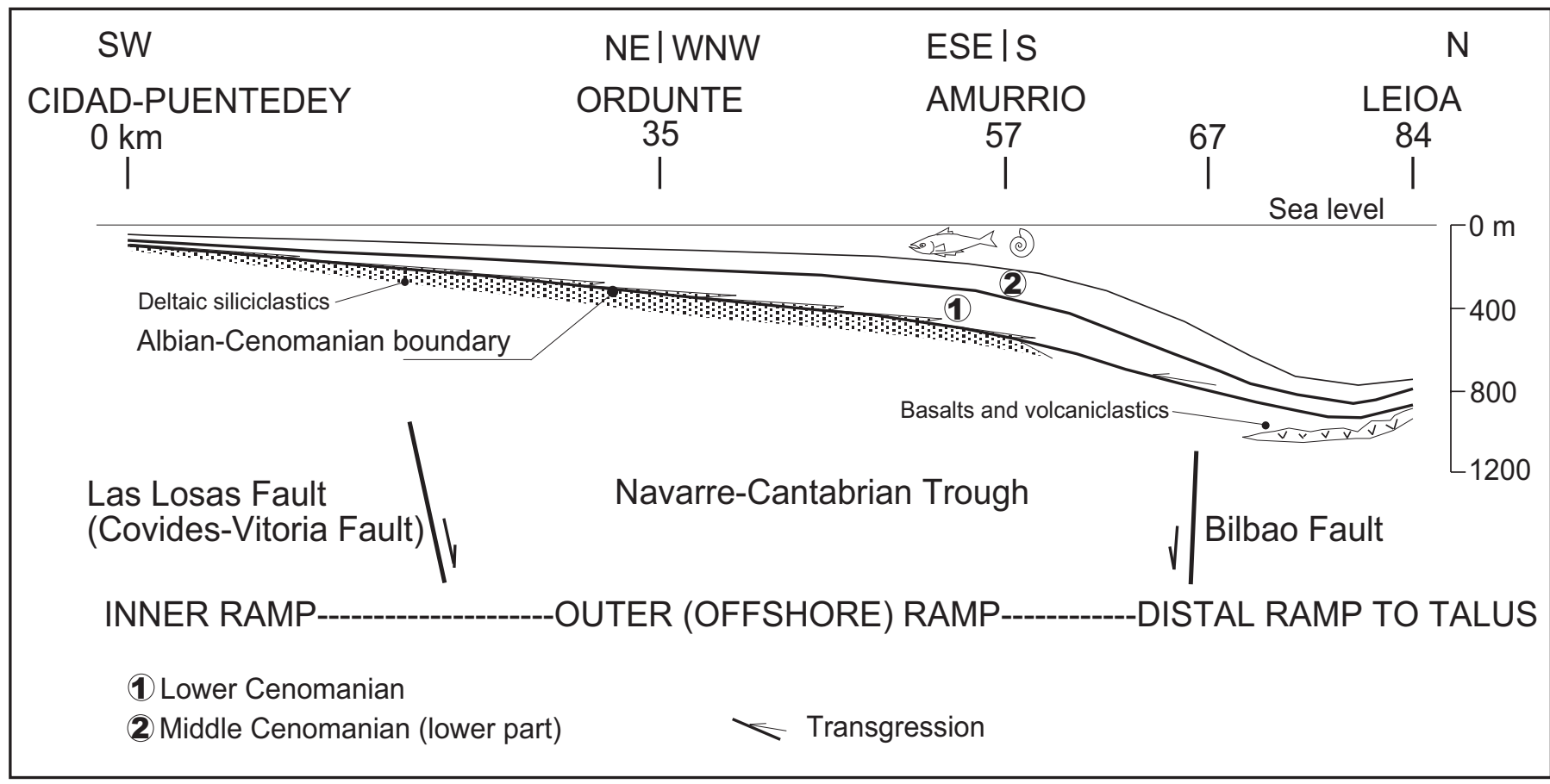

Fig. 4.- Cross-section of the Cenomanian carbonate ramp system of the studied area, from the shallow marine Cidad-Puentedey area (North Castilian Platform) via the offshore marine Amurrio-Aiara area (Navarre-Cantabrian Trough) to the distal marine basin of the Leioa area (Basque Trough), reconstructed to the early Middle Cenomanian when new studied faunas flourished. The Navarre-Cantabrian Trough represented a shallow marine area with tectonic control of the subsidence inherited from the Albian, that recorded the most complete Cenomanian succession and was correlative to the south to less subsident shallower areas prone to stratigraphical condensation and erosion, and to the north to a less subsident deeper-marine starved basin. Correlation is based on main stratigraphic sections (Figs. 1 and 3) and intermediate observations. See text for further explanations. 
lation of the carbonate ramp during the early Middle Cenomanian, highlighting the thickness variations of the Lower to Middle Cenomanian deposits from shallow inner areas to the WSW (Cidad-Puentedey) to outer ramp (around $200 \mathrm{~m}$ deep, Amurrio) and deep basinal areas (Leioa).

Deltaic siliciclastic deposits of the uppermost Albian were replaced by a carbonate ramp after the onset of the fast transgression that occurred in the study area during the earliest Cenomanian. In the Leioa area, the volcanism reduced drastically its influence during the Albian-Cenomanian transition, becoming absent during the rest of the Cenomanian and scarce during the Turonian-Santonian interval. Volcanic activity became really important to the southeast of the study area, in the Elgoibar area, for Turonian-Santonian times (e.g., Lamolda et al., 1983; Castañares et al., 1997). In this situation the Leioa area underwent a phase of relative cooling during the early Cenomanian wich, together with the generalized transgression, led to the subsidence and fast deepening of the area. According to Rodríguez-Lázaro et al. (1998), the Leioa area was, during the Cenomanian, dominated by intermediate waters indicative of more than $500 \mathrm{~m}$ in depth. Latest Albian submarine volcanic activity in the Leioa area occurred in depths around $100 \mathrm{~m}$ (López-Horgue and Bodego, 2012). These bathymetry changes indicate an abrupt increase of the water depth and the drowning of the volcanic area in the basin at the end of the Albian (Leioa), and the progressive increase of the water depth with the shift of the coastal siliciclastic deposits to the south at the beginning of the Cenomanian.

The new ecological conditions mark the disappearance of the ammonite family Brancoceratidae (Mortoniceras and Cantabrigites spp.) in the study area (Leioa and Amurrio areas) during the latest Albian and the appearance and rapid radiation of the family Acanthoceratidae (Graysonites sp., derived from the last Lyelliceratidae) at the beginning of the Cenomanian (in Ordunte area; see fig. 2). These bioevents occurred almost at the same time in Tethyan, European and North-American basins (e. g., Wright et al., 1996; Gale et al., 2011).

Carbonate ramp sedimentation prevails during all of the Cenomanian, but with different stratigraphic records. The stratigraphic record of Early Cenomanian age (4 Ma) shows thickness changes from around $30 \mathrm{~m}$ in Puentedey to 160 $\mathrm{m}$ in Amurrio and $70 \mathrm{~m}$ in Leioa. Middle and Upper Cenomanian sediments in Puentedey (North Castilian Platform; Wiedmann, 1979; bed 1 of Barroso-Barcenilla et al., 2011b) are 50 and $12 \mathrm{~m}$ thick respectively. Their coeval sediments in the Amurrio area are $400 \mathrm{~m}$ and $200 \mathrm{~m}$ thick respectively, and only $45 \mathrm{~m}$ and $10 \mathrm{~m}$ thick respectively in the basinal area at Leioa. This striking thickness variations depict a condensed shallow marine area, a sediment-starved deep marine area and a highly subsiding Navarre-Cantabrian Trough that received most of the sediments (Figs. 2 and 3). Continuous and increasing subsidence in the Navarre-Cantabrian Trough leading to accommodation creation can explain the progressive preservation of sediments after increasing sedimentation rate from Middle to Late Cenomanian (600 m thick succession in $2.5 \mathrm{Ma}$ ) and the maintenance of the overall depth conditions (around 200 m; Gräfe and Wendler, 2003).

Sediments of late Middle Cenomanian age from the Leioa area (Fig. 2) contain a low diversity fauna of benthic foraminifera and ostracods, together wih intervals that are free of these faunas (ostracod-free, OF, or benthic-free, BF, inter$\mathrm{val}$ ), indicative of hypoxic to anoxic conditions at the sea bottom that led to faunal turnovers in the ostracod assemblages (Rodríguez-Lázaro et al., 1998). Two important positive excursions in the $\delta^{13} \mathrm{C}$ curve are detected in the same interval in Leioa, indicating the burial of organic matter in that hypoxic bottom (MCE 1a and 1b of Mitchell et al., 1996; RodríguezLázaro et al., 1998).

The fish and ammonite from Aiara occur in the marly limestones of the lower Middle Cenomanian. The incursion of shallow waters into the Leioa area during this time and the related enrichment in nutrients (Rodríguez-Lázaro et al., 1998) suggest the renewal of the oceanic waters.

After this Middle Cenomanian transgression, the long-term increasing trend of the $\delta^{13} \mathrm{C}$ initiated earlier is consistent with a reduced nutrient availability to benthic microorganisms in the Leioa basin area (Rodríguez-Lázaro et al., 1998). This trend is also consistent with the long-term increasing sea level during the Cenomanian that led to the onset of the OAE2 in the latest Cenomanian (Gale et al., 2002; time-scale of Ogg and Hinnov, 2012). The Late Cenomanian transgression may have led to the expansion of the oxygen minimum zone from the basin area (Leioa) to the outer ramp (Amurrio-Aiara), therefore explaining the hypoxic conditions of the shelf bottom indicated by the ostracod assemblages (Rodríguez-Lázaro et al., 2003). Rotalipora spp. show an abrupt decline and extinction prior to the Cenomanian-Turonian boundary (circa $25 \mathrm{~m}$ before the C-T boundary in the Menoyo section, near Amurrio, Gorostidi and Lamolda, 1991; circa $8 \mathrm{~m}$ after the onset of the Rotalipora decline event in Leioa, RodríguezLázaro et al., 1998; in the M. geslinianum Zone, $2.6 \mathrm{~m}$ before the C-T boundary in Puentedey, Barroso-Barcenilla et al., 2011b). The first occurrence of the calcareous nannofossil Quadrum gartneri PRINS and PERCH-NIELSEN is the selected bioevent for the C-T boundary in the Menoyo section (Gorostidi and Lamolda, 1991; Lamolda and Peryt, 1998). The last occurrence of Rotalipora spp., and the occurrence of Mammites nodosoides (SCHLÜTER) $80 \mathrm{~m}$ above the C-T boundary (Menoyo section; Wiedmann, 1979; Lamolda, 1979) are in agreement with the secondary biostratigraphic markers in the GSSP for the base of the Turonian of Pueblo (Kennedy et al., 2000).

According to a proxy for sea-level change based on planktic-benthic microfossil ratios converted by palaeoslope model, Gräfe and Wendler (2003) recognize three major periods of sea-level rise during the Cenomanian of the BCB at 97.5 (Early), 95.2 (latest Middle) and 93.8 ma (latest). Despite the fact that their proxy does not predict major sea-level falls in the Cenomanian, this general transgressive tendency is punc- 
tuated by relative sea-level falls and the record of lowstand deposits. These deposits form the base of Arceo beds above UC3 unconformity and the base of Hijuela beds above UC4 unconformity, in the upper middle to upper Cenomanian, and the base of Cabezas beds above UC5 unconformiy in the topmost Cenomanian (Gräfe, 1994; Gräfe and Wiedmann, 1993; Gräfe and Wendler, 2003; see figure 3). Distributions of benthic foraminifera (typical of outer shelf) and the planktic/benthic ratios (around $50 \%$ ) in the Cenomanian of the Villasana area support the above comented relative sea-level changes but no substantial depth-variations (Gräfe and Wendler, 2003).

\section{Systematic palaeontology}

This section presents new invertebrate and vertebrate record of biostratigraphic and palaeoecological significance. These new records, together with the new model presented above, provide a new insight on the faunal replacements associated with this marine transgression.

\subsection{Ammonite new record}

Suborder Ammonitina Hyatt, 1889

Superfamily Acanthoceratoidea Grossouvre, 1894

Family Acanthoceratidae Grossouvre, 1894

Subfamily Acanthoceratinae Grossouvre, 1894

Genus Calycoceras Hyatt, 1900

Subgenus Newboldiceras Thomel, 1972

\section{Calycoceras (Newboldiceras) asiaticum spinosum}

(Kossmat, 1897)

Figure 5

1897 Acanthoceras newboldi var. spinosa Kossmat, p. 7(114); pl. 2(13), figs. 2, 3; pl. 3(14), fig. 1.

1990 Calycoceras (Newboldiceras) asiaticum spinosum (Kossmat, 1897), Wright and Kennedy, p. 249, pl. 64, fig. 3; pl. 65 , fig. 4, and others (with synonymy).

2004 Calycoceras (Newboldiceras) asiaticum spinosum (Kossmat, 1897), Kennedy and Jolkicev, p. 376, pl. 3, figs. 7, 10, 11; pl. 4, figs. 1-5; pl. 5, figs. 6-11 (with additional synonymy).

Referred material. Specimen MCNA 14392: part and counterpart of a crushed fragmentary internal mould corresponding to the end of the phragmocone and most of the body chamber.

Description. Narrow and high ribs cross the venter and are separated by slightly wider interspaces. The best preserved one third of a whorl, corresponding to the body chamber, bears 17 ribs. Primary ribs bear strong spiny umbilical tubercles, less marked inner ventrolateral tubercles and well marked clavate outer ventrolateral and siphonal tubercles. Inner ventrolateral and siphonal tubercles tend to decrease in strength adorally. Secondary ribs with both ventrolateral and siphonal tubercles are intercalated between primaries and do not reach the umbilical shoulder. The reconstructed whorl section is depressed.

Measurements (mm; reconstructed): diameter, 65.0, whorl height, 17.0, whorl width, 21.0.

Discussion. The dense ribbing, style and persistence of the tuberculation together with the polygonal whorl section are features that characterise the $C$. (Newboldiceras) asiaticum species. The strength of the ribs and that of the umbilical tubercle are typical features of the spinosum subspecies. Despite the preservation of the specimen, the suggested diameter and whorl section together with the ontogenetic changes in the ornament indicate the onset of the adult stage of the specimen in the outermost part, in which inner ventrolateral and siphonal tubercles tend to disappear. The specimen described here differs clearly from the less depressed and less sculptured C. (N.) asiaticum asiaticum subspecies. C. (N.) hippocastanum is a strongly sculptured species but with wider ribs and very depressed whorl section. The specimen is distinctive from other species of $C$. $(N$.) which are less sculptured, less depressed and with wider ribbing at a similar growth stage. Among other Acanthoceratinae, a similar shell sculpture is observed only in Eucalycoceras, but the latter differs in its denser ribbing with more separated umbilical and inner ventrolateral tubercles and commonly bullate tubercles, and in its compressed whorl section (e. g., Wright and Kennedy, 1990).

Occurrence. This new specimen occurs in the uppermost part of the "Lower Campillo beds" of the Amurrio-Aiara area The occurrence of this subspecies in the study area indicates a non-basal Middle Cenomanian age: T. acutus Subzone of the A. rhotomagense Zone, and A. jukesbrownei Zone. In equivalent sediments to the west (Valle de Mena area), the "Campillo beds" yield Calycoceras gr. C. newboldi (Wiedmann, 1979). In the same area, C. newboldi spinosum (Kossmat) and C. newboldi madagascariense Collignon are recorded from the overlying "Hijuela beds", dated as early Late Cenomanian (Wiedmann, 1979). This subspecies also occurs in Middle Cenomanian sediments from the Santander area of the Basque-Cantabrian Basin (Wilmsen et al., 1996; Wilmsen, 1997). This species is a component of the great diversification of Acanthoceratidae during the Middle Cenomanian (Wright et al., 1996).

Distribution of the species. This is one of the most widely spread species of Acanthoceratidae occurring in Europe, Asia, North America and Africa characterising the non-basal Middle Cenomanian; in England it also occurs in the lower Upper Cenomanian Calycoceras (Proeucalycoceras) guerangeri Subzone (Wright and Kennedy, 1990).

\subsection{New teleostean fish record}

Superclass Osteichthyes Huxley, 1880

Class Actinopterygii Klein, 1885

Infraclass Neopterygii Regan, 1923

Division Teleostei Müller, 1844 


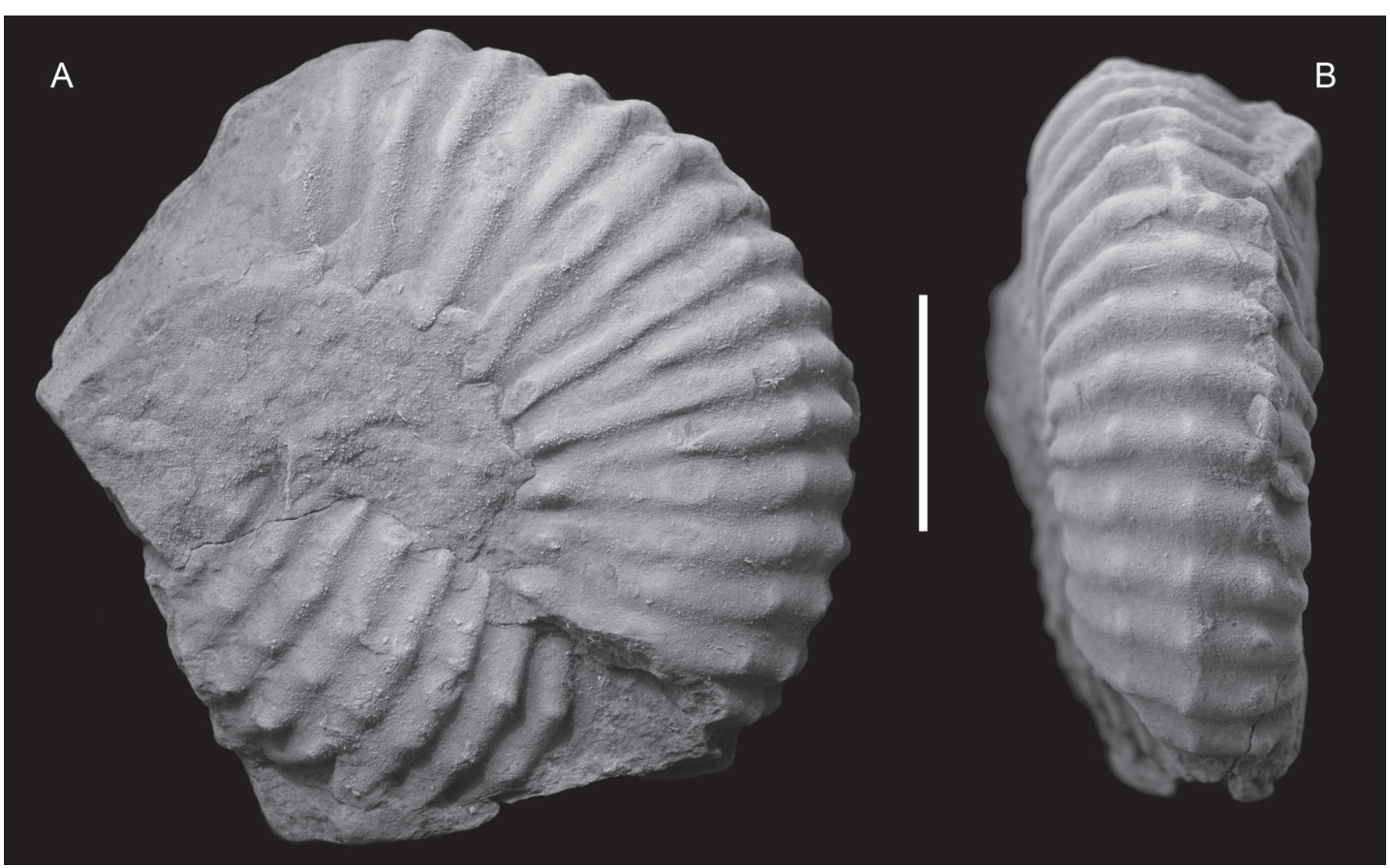

Fig. 5.- Calycoceras (Newboldiceras) asiaticum spinosum (Kossmat, 1897). Specimen MCNA 14392. A. Side view of the body chamber and ventral view of the twisted phragmocone fragment. B. Ventral view of the body chamber. Middle Cenomanian, fish-bearing marly limestones of Izoria, near Amurrio (Araba, Basque Country; Spain). Scale bar equals $2 \mathrm{~cm}$. Photos: M. A. López-Horgue.

Order Crossognathiformes Taverne, 1989

Suborder Pachyrhizodontoidei Forey, 1977

Family Pachyrhizodontidae Cope, 1872

\section{Description and comparison}

General morphology. The fish specimen (Fig. 6) is in anatomic connection and nearly complete, showing its left side in lateral view. The head is exhibited in its entirety (Fig. 7), the anteriormost part only as an impression; the rest of the skull is complete but poorly preserved, showing very few anatomic details. The abdomen and most of the caudal region are nearly complete (Fig. 6), with the scales shown in lateral view and a good number of vertebral centra protruding through the squamation. The caudal fin is entirely missing.

The anterior contour of the specimen is recognizable; the dorsal and ventral contours posterior to the maximum height are worn out, but they still provide significant information about the overall shape of the fish. The body is markedly fusiform, nearly ovoid (Fig. 6). The head is triangular, very pointed (Fig. 7). Both features correspond to the general morphology typical of most Crossognathiformes, most notably of the Pachyrizodontoidei, among other teleosts.

The preserved portion of the specimen measures about 350 $\mathrm{mm}$ from the tip of the snout to the posterior side of the last visible vertebral centrum. The general shape of the body suggests that this vertebral centrum is part of the caudal pedicle, indicating that the preserved length is only slightly shorter than the actual standard length. However, this is the only indication, since the caudal fin, including the ural endoskel- eton, are entirely missing. Even so, a conservative estimation suggests that the individual in life probably measured well above $400 \mathrm{~mm}$ of total length, with the standard length probably somewhere between 350 and 400 . For the rough estimation of the morphometric measures provided below, we use this range of $350-400 \mathrm{~mm}$ to provide a minimum estimation of each percentage ratio to the standard length.

The maximum body height is about $104 \mathrm{~mm}$, which results in, at most, $26-30 \%$ of the standard length. The head length is $107 \mathrm{~mm}$, resulting on a very similar percentage. The head height, measured from the ventralmost preserved border to the supraoccipital, is about $53 \mathrm{~mm}$. Therefore, the head is about half as high as it is long.

Skull. The skull (Figs. 7, 8) is preserved in dorsolateral view making observable the skull roof but not the ventral region of the head. The imperfect preservation and artificial abrasion of the specimen (Fig. 7A) have resulted on presenting a number of recognizable skull bones, but very few clearly recognizable borders, canals, pores, or other anatomical features. For this reason, the general arrangement of some dermal skull bones can only be estimated (Fig. 7B), but the precise shape, extent, and other features of most of these bones cannot be described in detail.

The anterior (ethmoid) region is preserved as a rough impression only, with no details. The mouth is tightly closed, and this, together with the partially dorsal view in which it is shown, prevents from observing the lower jaw. The infraorbitals cover most of the upper jaw, but we can note that the maxilla is very long, as in all crossognathiforms, and that there is at least one supramaxilla starting about midlength of the maxilla. 

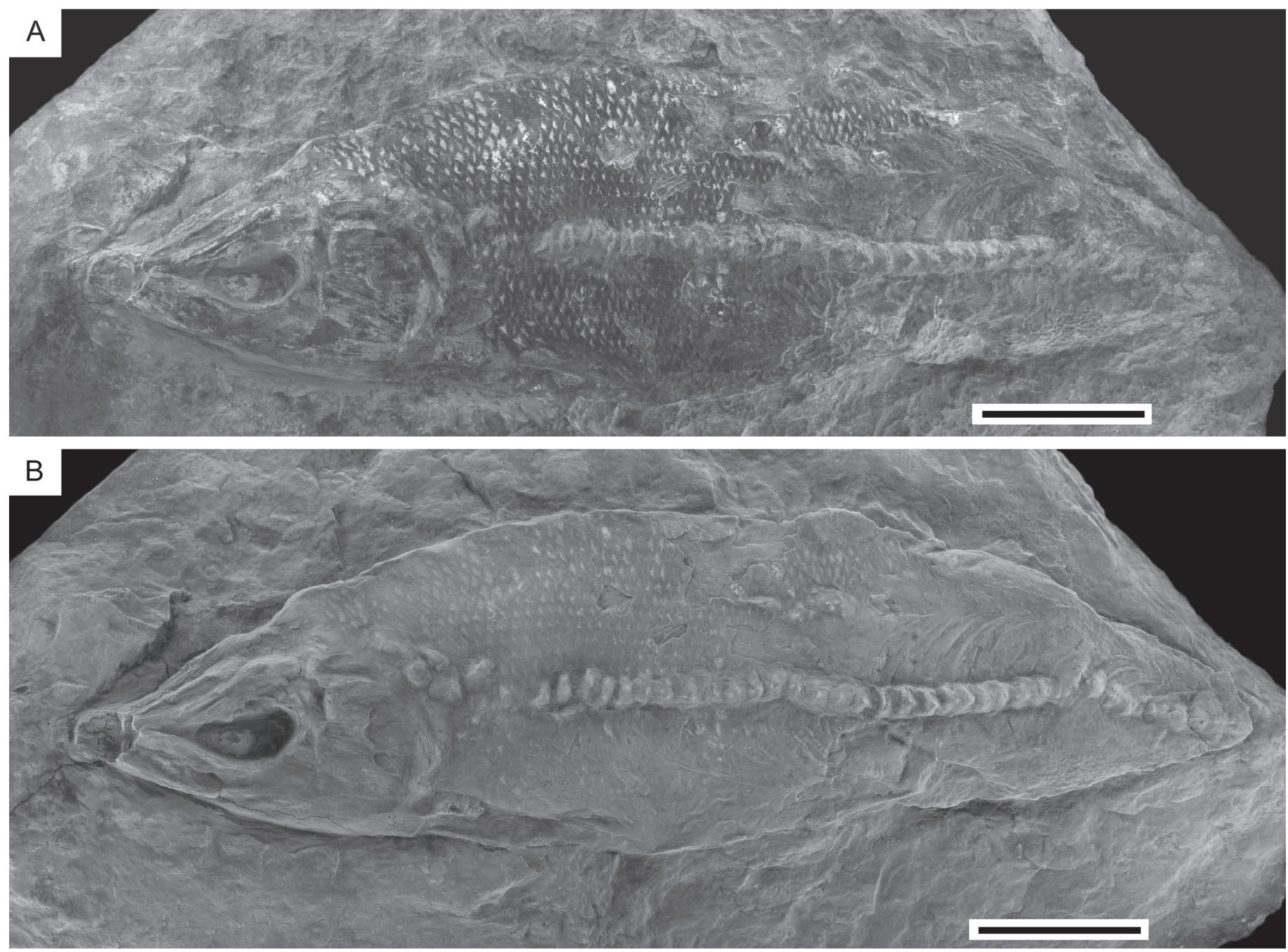

Fig. 6.- New Pachyrhizodontidae indet. from the Middle Cenomanian of Izoria, near Amurrio (Araba, Basque Country; Spain). Specimen Aztarna-1. A. Complete specimen, left side in lateral view. B. Same as A, coated with ammonium chloride. Scale bars equal $5 \mathrm{~cm}$. Photos: Z. Herrera.

The better preserved region is the skull roof, notably the frontals (Figs. 7, 8). They are very long and large, apparently wider anterior to the orbit than posterior to it. The outline of the frontals seems more similar to that of Pachyrhizodus than to any other crossognathiform. As in this genus (Forey 1977, fig. 25), they are long and very broad, with the maximum width just before the orbit, being comparatively narrower in their postorbital region. However, in the Amurrio specimen they do not have the median depression on the epiphyseal region present in Pachyrhizodus, Apsopelix (Teller-Marshall and Bardack, 1978, p.7. fig.1), Goulmimichthys (Cavin, 2001, p.513, fig.2B) and Nardopiscis (Taverne, 2008, p.21, fig.5). The frontals are not depressed but raised along their midline instead, so that the ensemble of both frontals forms an elevated median ridge along most of their length (Figs. 7, 8), as in Rhacolepis (Forey 1977, p.146). The lateral margin of the frontals is excavated at the posterodorsal border of the orbit above the autosphenotic (Fig. 8); this is a diagnostic character of the suborder Pachyrhizodontoidei (Cavin, 2001, p.533). The shape of lateral border of the frontal at the posterodorsal corner of the orbit seems to be part of the lateral ex- pansion of the autosphenotic, although the latter is only very partially visible. Such participation is absent in Rhacolepis (Forey 1977, fig. 10; Maisey 1991, fig. on p.249) and most other crossognathiforms, but is present in Goulmimichthys (Cavin, 2001, p.513, fig.2) and, apparently, Bavarichthys (Arratia and Tischlinger, 2010, fig.5). In addition to the median ridge formed by the elevation of both frontals, each frontal has another conspicuous longitudinal ridge (Fig. 7), probably lodging the supraorbital sensory canal, as in Nardopiscis (Taverne, 2008, p.21, fig.3) and Rhacolepis (Forey 1977, fig.12). Each paired ridge and the median ridge limit a relatively deep, wide depression along most of the length of each frontal. This complex type of relief and the convex but smooth postorbital expansion suggest that there are no radiating ridges on the surface of the frontals.

The parietals are not so well preserved (Fig. 8); they are small bony plates separated from each other by the supraoccipital, whose serrated and curved posterior border suggests the presence of a supraoccipital crest (Fig. 8), apparently quite shorter than in Rhacolepis (Forey 1977, fig.12). The skull is, therefore, lateroparietal. A bony plate postero-lateral 

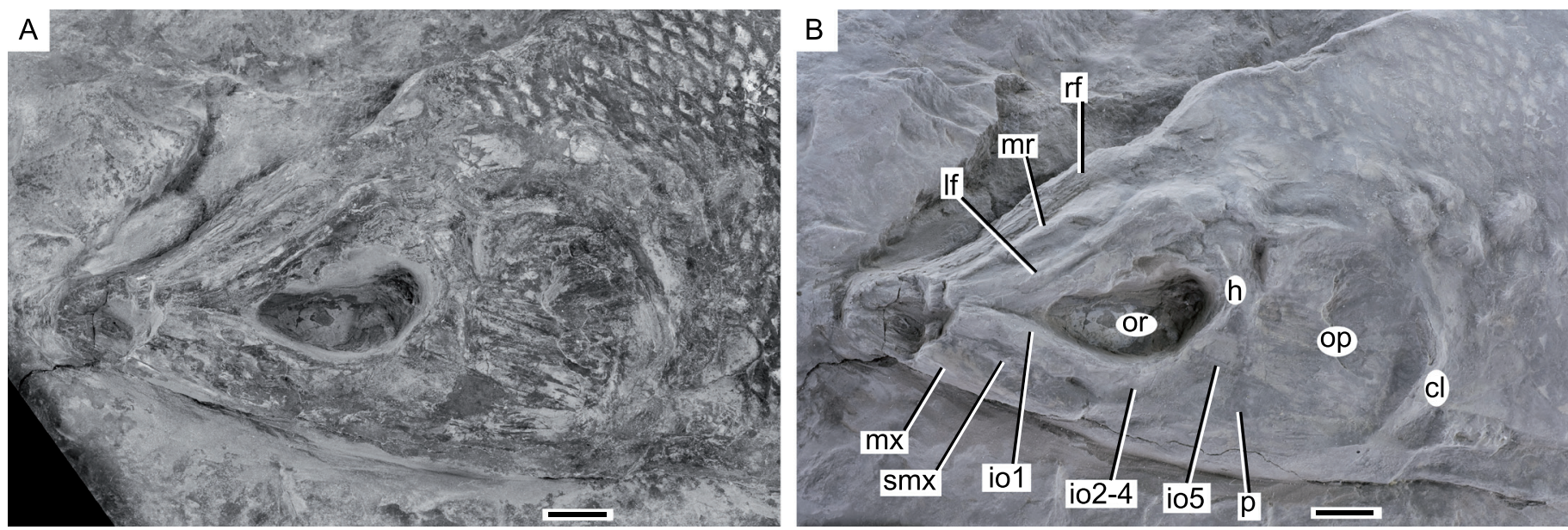

Fig. 7.- Skull of the new Pachyrhizodontidae indet. from the Middle Cenomanian of Izoria, near Amurrio (Araba, Basque Country; Spain). Specimen Aztarna-1. A. Head of specimen, left side in lateral view. B. Same as A, coated with ammonium chloride. Abbreviations: cl, cleithrum; h, hyomandibular; io1, infraorbital 1 (autogenous); io2-4, infraorbitals 2-4 (fused); io5, infraorbital 5 (autogenous); lf, left frontal; mx, maxilla; mr, median ridge formed by left and right frontals; op, opercular bone; or, orbit; $\mathrm{p}$, preopercular bone; rf, right frontal; smx, supramaxilla. Scale bars equal 1 cm. Photos: Z. Herrera.

to each parietal, and quite larger, must correspond to the extrascapular bones. Some sensory pores indicate the presence of the extrascapular commissure; a single pair of large and wide extrascapulars is apparently present.

The infraorbital region is also quite peculiar (Fig. 7). The first infraorbital seems autogenous, and it largely covers the supramaxilla (e) plus a good extent of the maxilla. More notably, a single bony plate seems to cover the area usually occupied by the second, third, and fourth infraorbitals in Aquilopiscis, Chongichthys, Goulmimichthys, Nardopiscis, Pachyrhizodus, Rhacolepis, and Varasichthys. In the Amurrio fish, there is a clear suture separating this plate from the fifth infraorbital, but there is no other suture within this single bony plate. If so, it would represent a fusion of the second, third, and fourth infraorbitals. This plate is consequently very long, but also very large ventrally and, especially, posteriorly. Fusion of infraorbitals is not unheard of among crossognathiforms. Five autogenous infraorbitals are present in Aquilopiscis (Cumbaa and Murray, 2008, fig.6), Goulmimichthys (Cavin, 2001, fig.5), Varasichthys (Arratia, 2008 fig.3a), and most likely Chongichthys (Arratia, 2008, fig.6a) and Nardopiscis (four infraorbitals plus a dermosphenotic in the position of the fifth infraorbital: Taverne, 2008, fig.3). In turn, infraorbitals two and three are fused in Pachyrhizodus (Forey 1977, fig.30) and Rhacolepis (Forey 1977, fig.20; Arratia, 2008, fig.6b); infraorbitals 4 and 5 are fused in Bavarichthys (Arratia and Tischlinger, 2010, fig.5); and infraorbitals 2 and 3, and, separately, infraorbitals 4 and 5, are fused in Michin (Alvarado-Ortega et al., 2008, fig.2). The only crossognathiform with apparently a similar pattern, fusion of infraorbitals two, three, and four into a single bony plate, is Apsopelix anglicus (Teller-Marshall and Bardack, 1978). The pattern of the latter species, however, should be regarded with caution because of the fragmentation of the infraorbital series in the available specimens.
The posterior infraorbitals are very large. Their posterior border, although not entirely preserved, seems to cover a good part of the dorsal limb of the preopercular bone, more as in Pachyrizodus than as in Bavarichthys or Rhacolepis; however, it does not seem to reach the opercular bone, as in Goulmimichthys (Cavin, 2001).

The opercular bone (Fig. 7) is very large, occupying nearly one third of the head length, more than in most crossognathiforms; for instance, it occupies only about one fifth in Rhacolepis (Forey 1977, fig.20). It is roughly quadrangluar in contour, very much as in Nardopiscis (Taverne, 2008, fig.3). The morphology of the dorsal region of the preopercular bone is unveiled by its slightly uplifted borders. This bone is very narrow, and its limbs form a straight angle with a very small expansion at it. Although it is not well exposed, the anteroventral limb of the preopercular bone seems rather short, as in most crossognathiforms.

Fins, vertebrae, and squamation. Fins are mostly missing, although the pectoral girdle is preserved, and there is also some indication of the position of the dorsal fin. The pectoral girdle is almost entirely, but badly, preserved. The cleithrum is broad, with a broad but short anteroventral expansion. A long, broad plate between the cleithrum and the extrascapular is probably the posttemporal; remains of a smaller supracleithrum seem to be present as well. In articulation with the posterior border of the cleithrum, a narrow scapula and a broad coracoid are visible; the presence of a postcleithrum cannot be confirmed. No remains of the pectoral fin rays are preserved.

Very scarce, tiny basal fragments of the anteriormost fin rays indicate that the dorsal fin is inserted at about $225 \mathrm{~mm}$ from the tip of the snout, at about $57-64 \%$ of the estimated standard length; that is, behind the mid-length of the body. The ventral border of the body in the posterior part of the caudal region is not preserved, so no traces of the pelvic and 


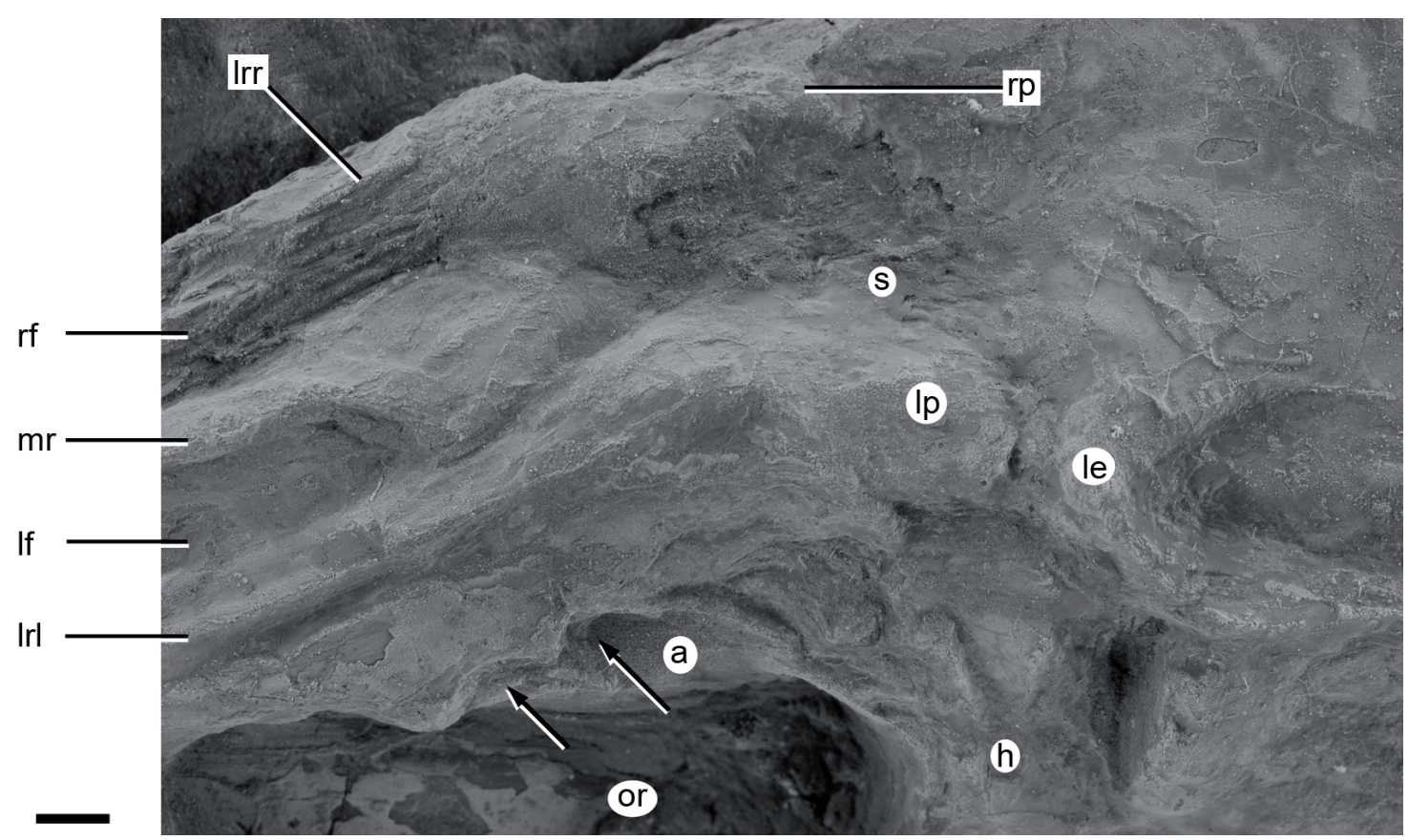

Fig. 8.- Skull of the new Pachyrhizodontidae indet. from the Middle Cenomanian of Izoria, near Amurrio (Araba, Basque Country; Spain). Specimen Aztarna-1. Detail of the posterolateral region of skull roof. Abbreviations: a, autosphenotic; h, hyomandibular; le, left extrascapular (partially preserved); lf, left frontal; lp, left parietal; lrl, lateral ridge of left frontal; lrr, lateral ridge of right frontal; mr, median ridge formed by left and right frontals; or, orbit; rf, right frontal (partially preserved); rp, right parietal (partially preserved); s, supraoccipital bone (partially preserved; notice the serrated posterior border). Arrows point the excavation at the lateral margin of the frontals in the posterodorsal border of the orbit. Scale bar equals $3 \mathrm{~mm}$. Photo: Z. Herrera.

anal fins are observed. The caudal pedicle and fin are entirely missing.

Many vertebrae are partially visible protruding through the scales (Fig. 6). There are at least 33 vertebrae; 3-5 more vertebrae must have occupied the spaces before and among the exposed vertebrae. An undeterminable number of caudal vertebrae were present posterior to the last one preserved. It is not possible to estimate how many of the preserved vertebrae are abdominal. Each vertebra appears to be very constricted in the middle. Because matrix covers the lateral sides, a possible relief at the surface of centra cannot be observed. Some neural spines are visible in the posterior part of the specimen, but it is not possible to discern whether the corresponding arcocentra are fused or autogenous.

The scales are generally well preserved (Fig. 6). They are leptoid, apparently cycloid, small and very tightly arranged. Some 23-25 longitudinal scale rows can be estimated in the highest point of the body. About 40 complete transversal rows can be estimated between the posterior border of the pectoral girdle and the point of insertion of the dorsal fin; some 12 incomplete transversal scale rows can be counted between the posterior border of the skull and the first complete transversal row.

Taxonomic assessment. The poor preservation of the specimen, notably the dermal skull, and the lack of most fins, including the caudal endoskeleton, renders comparisons very difficult and strongly advises against a generic assessment of the specimen.
The specimen lacks the caudal endoskeleton, with its essential characters; however, the supraoccipital forming part of the skull roof and the presence of leptoid (not ganoid) scales clearly shows that it is a teleostean fish. Beside the general, typical shape of the body and head, the Amurrio fish seems to present the only unique character of the Crossognathiformes according to Arratia (2008): a single pair of large and well-developed extrascapular bones. However, none of the homoplastic characters that combine to define the order can be checked in the specimen. As pointed above, the frontal margin excavated above the autosphenotic indicates that it is a Pachyrizodontoidei (Cavin, 2001).

Within the Pachyrhizodontoidei, we cannot check any character of the family Pachyrhizodontidae in the Amurrio fish, because all diagnostic characters (Cavin, 2001, p.533) are provided by the caudal fin and endoskeleton, and these are entirely missing in the specimen. However, it does not present the cranial diagnostic characters of the other family, the Notelopidae, that can be checked: fusion of infraorbitals $4+5$ and skull roof medioparietal (reversal; Cavin, 2001, p.533). The fish can, therefore, be referred to the Pachyrhizodontidae with great caution, because it does not belong to the other family of the suborder. In any case, this is the first report of a Pachyrhizodontoidei from the Iberian Peninsula.

Within the Pachyrhizodontidae, it resembles Pachyrhizodus and Rhacolepis rather than Goulmimichthys in the fusion of some infraorbitals, although they are not exactly the same (see above). As a matter of fact, fusion of infraorbitals (1 and 
2 or 2 and 3) is considered a character typical of the suborder Pachyrhizodontoidei (Forey 1977, pp.128-129; Cavin, 2001, p.533). Fusion of infraorbital bones also occurs in crossognathids, a feature regarded as an evidence of close relationships with pachyrhizodontoids by Taverne (1989), but as a trend present in parallel in both lineages by Cavin (2001). The crossognathids Apsopelix possibly shares with the Amurrio fish a similar infraorbital bones pattern, but Apsopelix differs by several other characters, such as a medial depression at the posterior level of the frontals, a medioparietal skull roof, and the frontals tapering anteriorly (Teller-Marshall and Bardack, 1978).

Among the Pachyrhizodontidae, the new fish is notably similar to Pachyrhizodus megalops, from the Cenomanian of England, and to Rhacolepis, from the Aptian of Brazil, in some particular features of the frontal bones, as presented above. However, the combination of the characters of the frontals of the Amurrio fish seems to be unique; the fusion of infraorbitals $2+3+4$ is also unique among all crossognathiform genera.

\subsection{Phylogenetic and palaeobiogeographic comments on Pachyrhizodontoidei}

Pachyrhizodontoidei are generally grouped with the Crossognathidae within the Crossognathiformes (Taverne, 1989; Arratia, 2008), although an alternative view considering the crossognathids as basal teleosts and the pachyrhizodontoids as basal euteleosts has also been proposed (Cavin, 2001; Cumbaa and Murray, 2008).

The discrepancy between both phylogenetic patterns makes the recognition of a clear palaeobiogeographical signal difficult. In both alternative phylogenetic hypotheses, however, Rhacolepis, Goulmimichthys, Pachyrhizodus and Aquilopiscis (the latter two genera are not included in Arratia, 2008) form the clade Pachyrhizodontidae, to which the Amurrio fish likely belongs (see above). Although not included in any phylogenetic analysis, Michin csernai is regarded as the basal member of the family Pachyrhizodontidae (Alvarado-Ortega et al., 2008). Kansanus martini, from the Late Cretaceous Niobrara Formation in Kansas, USA, is now referred to Pachyrhizodus sp. (Shimada and Fielitz, 2006). The geographic distribution of pachyrhizodontids is mapped for three time intervals: the Albian, Cenomanian-Turonian, and Coniacian-Maastrichtian (Fig. 9). In the Albian, the genus Pachyrhizodus is present in Europe (P. salmonensis) and Australia, (P. marathonensis), and Rhacolepis is present, possibly with two species, in several localities from Brazil. In the Cenomanian, the genus Pachyrhizodus diversified, with five recognized species in the British Lower Chalk; the occurrence of the Amurrio specimen is isochronous with this radiation. Three species of Pachyrhizodus are known in the Cinto Euganeo locality, Italy, which is dated as CenomanianTuronian boundary. In the Turonian, one species of Pachyrhizodus is recorded in the British Middle Chalk, one in the
Greenhorn Formation in Nebraska, USA, and another one in the locality of Vallecillo in Mexico. In this stage, the genus Goulmimichtys also occurs, with one species from Goulmima, Morocco, one from Vallecillo, Mexico, and possibly one from the Formation Villeta in Columbia (Páramo-Fonseca, pers. com.). The genus Aquilopiscis is known from the Turonian of Canada. After the Turonian, several occurrences of Pachyrhizodus are recorded in the Late Cretaceous of North America, as well in the Maastrichtian of Europe and New Zealand. Nardopiscis, from the Campanian-Maastrichtian of Nardò, Italy, may represent another occurrence (Taverne, 2008), but its phylogenetic position among the Pachyrhizodontoidei remains unclear.

The interpretation of the distribution of the pachyrizodontids in time and space is difficult because the phylogenetic relationships between the Pachyrhizodus species, as well as the monophyly of the genus, are unclear, and because the quality of the fossil record is very variable in time and space. For instance, the richness of the fish record from the British Chalk may be responsible for the diversification of the genus Pachyrhizodus observed in these deposits, and a similar situation occurs for the observed diversification of the genus in the Coniacian-Campanian of North America. However, some general trends can be detected, supplementing the preliminary pattern proposed by Cavin (2008). The genus Pachyrhizodus, if monophyletic, is the most specious genus of the family. All species occurred on northern landmasses, except one in the Albian of Australia and one in the Maastrichtian of New Zealand. These southern occurrences are not surprising if we consider this region, the easternmost extremity of Gondwana, as largely opens towards the Tethys. However, the absence of this genus in the very rich fish assemblages from the Cenomanian of the Lebanon results on a discontinuous distribution of the genus throughout the Tethys. The pachyrhizodontid representatives in Western Gondwana appear to differ from the taxa in Laurasia, with Rhacolepis in the Early Cretaceous and Goulmimichthys in the Turonian. The latter is known from a species in Mexico, which belongs to Laurasia, but in a locality showing affinities with the Gondwanian realm. Rather than focusing on the palaeobiogeographical affinities alone, it looks as if Pachyrhizodus was a taxon from temperate environments, whereas Michin, Rhacolepis, and Goulmimichthys were genera from more tropical environments. Interestingly, the Amurrio fish shows characters of both Rhacolepis and Pachyrhizodus, and was found in a locality situated in a rather low palaeolatitude compared to that of most Pachyrhizodus species.

The palaeobiogeographical observations mentioned here do not constitute a tested evolutionary scenario, but are rather hypotheses to be tested in further studies.

\section{Conclusions: integration of the new data}

The multidisciplinary approach to the Late Cretaceous marine transgression in Iberia presented in this paper integrates 


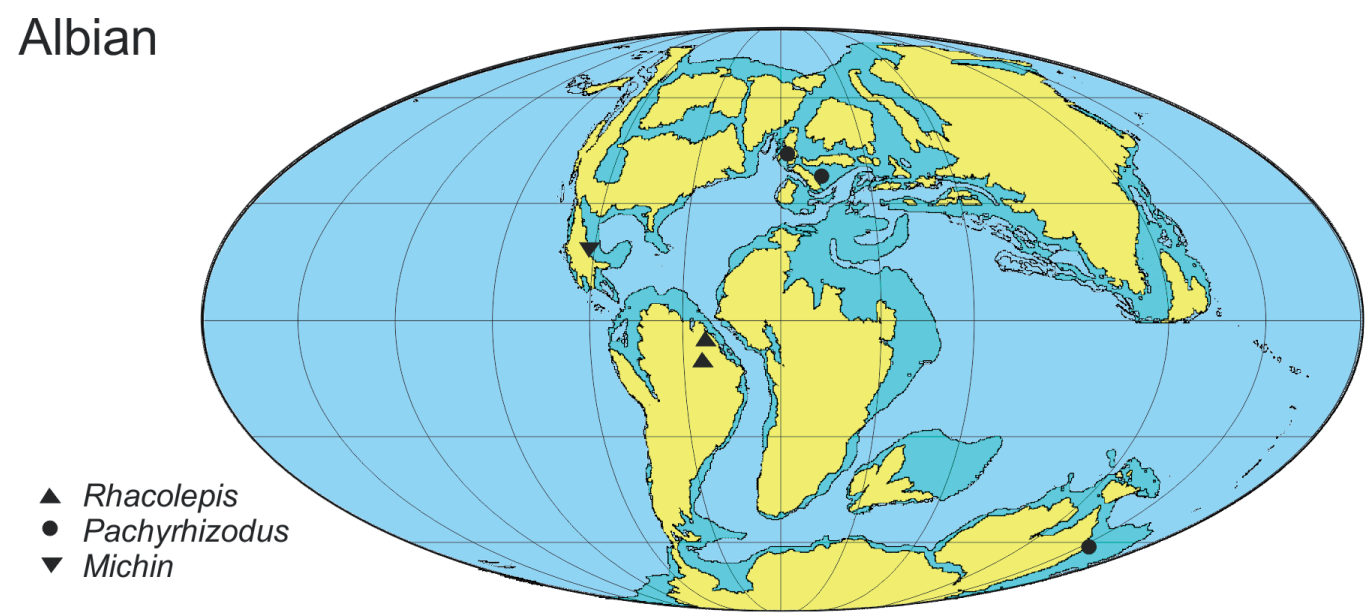

Fig. 9.- Palaeogeographic distribution of pachyrhizondontids for three time intervals: Albian, Cenomanian-Turonian and Coniacian-Maastrichtian.

\section{Cenomanian-Turonian}

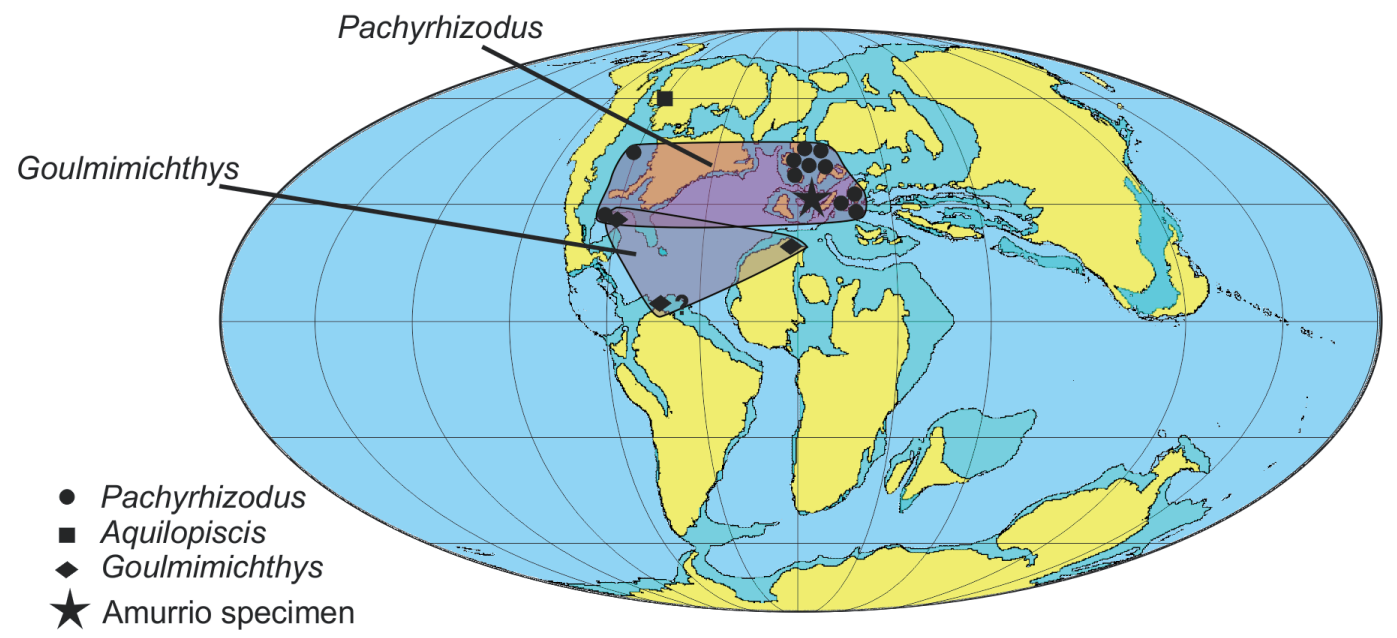

\section{Coniacian-Maastrichtian}

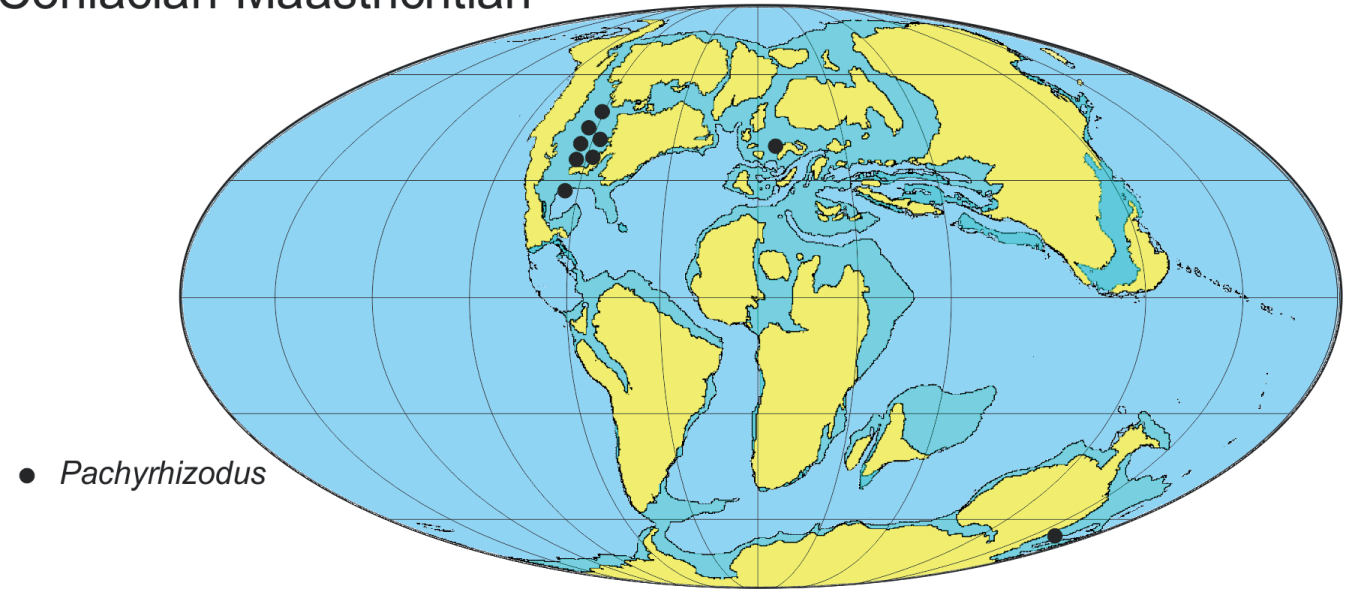

known and new stratigraphical and fossil record (ammonite and fish) data from the Cenomanian carbonate ramp succession deposited in the northern Iberian margin of the BasqueCantabrian Basin. The Albian-Cenomanian transition marks the onset of a progressive transgression and the diminishing of a striking differential subsidence, leading to larger areas of similar subsidence and sedimentary rate. The progressive flooding of the Iberian margin until the Santonian is at the origin of large shallow marine areas. A proposal of correlation of the Cenomanian ramp successions from shallowest areas in the south to a deep marine basin in the north has been supported by the revision of the known and new biostratigraphical data. This correlation has permitted to depict the striking differences in thickness. Very thin deposits (around $80 \mathrm{~m}$ ) originated in shallower areas that underwent episodic erosion/no deposition/condensation, especially during lower 
sea-levels. The thickest succession (almost $800 \mathrm{~m}$ ) was recorded in the subsiding Navarre-Cantabrian Trough. Thin condensed deposits (less than $140 \mathrm{~m}$ ) formed in a sedimentstarved deeper basin. Oceanographic changes described in the deep marine area by Rodríguez-Lázaro et al. (1998) and those described by Gräfe and Wendler (2003) have been used in connection to stratigraphy in order to understand the environmental changes.

Ammonites underwent a striking turnover within Acanthoceratoidea at the Albian-Cenomanian transition, with the extinction of Brancoceratidae before the Cenomanian and the appearance and rapid radiation of Acanthoceratidae at the beginning of the Cenomanian from a limited stock of Lyelliceratidae. In the studied area, more work is needed to accurately draw these changes; however, evidences support that this ammonite turnover occurred during the onset of the Late Cretaceous transgression, the deepening of the basin and the change from deltaic and deeper marine volcanic environments to marine carbonate ramps. The new specimen of Calycoceras (Newboldiceras) asiaticum spinosum described here is a component of an important diversification in Acanthoceratidae that took place at the Early-Middle Cenomanian transition. The association to the new fish in the same bed is of high biostratigraphic importance.

The new teleostean fish from the Middle Cenomanian is the first reported record of the order Crossognathiformes from the Cretaceous of the Iberian Peninsula. It lived in a distal shallow marine area, being the oldest evidence of another relevant faunal replacement in this part of Europe. During most of the Mesozoic, the fish faunas from the Tethys Sea (Western Tethys Ocean) and its continental domains were essentially formed by basal neopterygians. Such relatively primitive, non-teleostean forms constitute the basis of the typical marine Jurassic faunas from classic sites like Cerin (France; e.g., Saint-Seine, 1949) and Solnhofen (Germany, e.g., Frickhinger, 1994). These Jurassic faunas include taxa such as Amiiformes, Pycnodontiformes, and Ginglymodi. Ecologically, these fishes were the specialized ones: ichthyofagous, durophagous, insectivorous, and so on. Undisputed teleosteans did appear early in the Jurassic (Arratia, 2000, 2004); during that period and the Early Cretaceous, their diversity increased and their main basal evolutionary lineages appeared. However, they were mostly, if not exclusively, very generalized forms, small to middle-sized, fusiform bodied, with small or no teeth, and with a buccal apparatus typical of a suction mode of feeding. In the westernmost part of the Western Tethys Ocean and its continental domains, teleosteans occupied, for a very long time, the lowest levels of the fish trophic pyramid, with no recognizable specialized forms. Specialized groups such as pycnodonts and amiiforms managed to keep teleosteans out of their niches for a remarkably long time, an indication that the evolutionary novelties of the Teleostei per se were not enough to grant them immediate dominion in specialized niches until drastic changes in the environment did occur (Poyato-Ariza, 2005). In this sense, the fish faunas turnover in Western Europe during the EarlyLate Cretaceous would be linked to major transgression episodes, when specialized forms of basal neopterygians were replaced by teleosteans. The latter would be, from then on, the essential component of all bony fish faunas until today. The new Pachyrhizodontidae from Spain is, therefore, the oldest evidence of modern actinopterygian ichthyofaunas in Iberia. In this context, this finding is remarkable because it corroborates that the phenomenon of the faunal replacement taking place during the Late Cretaceous in this part of Europe is linked to a major marine transgression, a specific evidence that confirms general predictions based on previous ecomorphological studies (Poyato-Ariza, 2005; Poyato-Ariza and Martín-Abad, 2013). As a consequence, it confirms that, during the Mesozoic, teleosteans required major environmental changes for displacing more basal neopterygians from the most specialized niches of the trophic pyramid.

\section{Acknowledgements}

This work is a contribution to the University of the Basque Country (UPV/EHU) research project EHU09/11, and to the project CGL2013-42643-P of the Ministerio de Ciencia e Innovación de España. Financial support has been also provided by the University of the Basque Country (UPV/EHU) Research Group IT834-13. The photographs of this difficult fish specimen were painstakingly prepared and taken by $\mathrm{Za}$ rela Herrera at the Servicio de Fotografía Paleontológica of the Universidad de Zaragoza (Spain). Iñaki Rojo Legarra assisted during the field work. Goreti and Ramón from the Asociación Etnográfica Aztarna are acknowledged for the kind loan of the fish specimen. The revisions of Kai-Uwe Gräfe and an anonymous reviewer substantially improved the final version of the paper.

\section{References}

Alvarado-Ortega, J., Mayrinck. D. de, Brito, P.M. (2008): A basal Pachyrhizodontid fish (Actinopterygii, Teleostei) from the Lower Cretaceous of the Tlayúa Quarry, Central Mexico. Comptes Rendus Palevol. 7, 269-275. doi: 10.1016/j.crpv.2008.03.006

Arratia, G. (2000): Phylogenetic relationships of Teleostei. Past and Present. Estudios Oceanológicos 19, 19-51. ISSN 0071-173X

Arratia, G. (2004): Mesozoic halecostomes and the early radiation of teleosts, In: G. Arratia, A. Tintori, (eds.), Mesozoic Fishes 3. Systematics, paleoenvironments and biodiversity. Verlag Dr. Friedrich Pfeil, München, pp. 279-315. ISBN 3-89937-053-8

Arratia, G. (2008): The varasichthyid and other crossognathiform fishes, and the break-up of Pangea, In: L. Cavin, A. Longbottom, M. Richther (eds.), Fishes and the break-up of Pangea. Geological Society of London Special Publications 295, pp. 71-92. doi: 10.1144/SP295.6

Arratia, G., Tischlinger, H. (2010): The first record of Late Jurassic crossognathiform fishes from Europe and their phylogenetic importance for teleostean phylogeny. Fossil record 13, 317-341. doi: 10.1002/ mmng.201000005. 
Barroso-Barcenilla, F., Goy, A., Segura, M. (2009): Ammonite zonation of the Upper Cenomanian and Lower Turonian in the Iberian Trough, Spain. Newsletters on Stratigraphy 43, 139-164. doi: 10.1127/00780421/2009/0043-0139

Barroso-Barcenilla F., Callapez, P. M., Ferreira Soares, A., Segura, M. (2011a): Cephalopod assemblages and depositional sequences from the upper Cenomanian and lower Turonian of the Iberian Peninsula (Spain and Portugal). Journal of Iberian Geology 37 (1), 9-28. doi: 10.5209/rev_JIGE.2011.v37.n1.1

Barroso-Barcenilla, F., Pascual, A., Peyrot, D., Rodríguez-Lázaro, J. (2011b): Integrated biostratigraphy and chemostratigraphy of the Upper Cenomanian and Lower Turonian succession in Puentedey, Iberian Trough, Spain. Proceedings of the Geologists'Association 122, 67-81. doi: 10.1016/j.pgeola.2010.11.002

Cavin, L. (2001): Osteology and phylogenetic relationships of the teleost Goulmimichthys arambourgi Cavin, 1995, from the Upper Cretaceous of Goulmima, Morocco. Eclogae Geologicae Helvetiae 94, 509-535. doi:10.1006/zjls.2000.0284

Cavin, L. (2008): Palaeobiogeography of Cretaceous Bony Fishes (Actinistia, Dipnoi and Actinopterygii). In: L. Cavin, A. Longbottom, M. Richter (eds.), Fishes and the breakup of Pangaea. Geological Society of London Special Publication 295, London, pp: 165-183. doi: 10.1144/SP295.11

Cherchi, A., Schroeder, R. (1998): The Cenomanian at the Lahoz section (Prov. Alava). In: Lamolda, M.A. (ed.), $24^{\circ}$ Coloquio Europeo de Micropaleontología (libro-guía), Bilbao, pp. 61-64.

Cumbaa, S., Murray, A. (2008): New Late Cretaceous pachyrhizontid and enchodontoid fishes and associated ichthyofauna from the Northwest Territories, Canada. In: G. Arratia, H.-P Schultze, M.V.H. Wilson (eds.), Mesozoic Fishes 4 - Homology and Phylogeny, Verlag Dr. Friedrich Pfeil, München, pp: 229-256. ISBN 978-3-89937-080-5

Feuillée, P. (1967): Le Cénomanien des Pyrénées Basques aux Asturies. Essai d'analyse stratigraphique. Mémoires de la Société Géologique de France (nouvelle série), t. XLVI, fasc. 3, 1-343.

Floquet, M. (1989): Barres calcarénitiques tidales lors de la transgression marine dans le golfe Cantabrique au Cénomanien moyen (Espagne du Nord). Bulletin de la Société Géologique de France V (5), 1003-1013. doi:10.2113/gssgfbull.V.5.1003

Floquet, M. (2004): El Cretácico superior de la Cuenca Vasco-Cantábrica y áreas adyacentes. In: J. A.Vera (ed.), Geología de España, SGEIGME, Madrid, pp: 299-306. ISBN 84-7840-546-1

Forey, P. (1977): The osteology of Notelops Woodward, Rhacolepis Agassiz and Pachyrhizodus Dixon (Pisces: Teleostei). Bulletin of the British Museum (Natural History), Geology 28, 125-204.

Frickhinger, K. A. (1994): The fossils of Solnhofen. Goldschneck-Verlag (Korb, Germany), pp 333.

Gale, A. S., Hardenbol, J., Hathway, B., Kennedy, W. J., Young, J. R., Phansalkar, V. (2002): Global correlation of Cenomanian (Upper Cretaceous) sequences: Evidence for Milankovitch control on sea level. Geology 30, 291-294. doi:10.1130/0091-7613(2002)030<0291:GC OCUC $>2.0 . \mathrm{CO} ; 2$

Gale, A. S., Bown, P., Caron, M., Crampton, J., Crowhurst, S. J., Kennedy, W. J., Petrizzo, M. R., Wray, D. S. (2011): The uppermost Middle and Upper Albian succession at the Col de Palluel, Hautes-Alpes, France: An integrated study (ammonites, inoceramid bivalves, planktonic foraminifera, nannofossils, geochemistry, stable oxygen and carbon isotopes, cyclostratigraphy). Cretaceous Research 32, 59-130. doi: 10.1016/j.cretres.2010.10.004

García-Mondéjar, J., Fernández-Mendiola, P. A., Agirrezabala, L. M., Aranburu, A., López-Horgue, M. A., Iriarte, E., Martinez de Rituerto, S. (2004): El Aptiense-Albiense de la Cuenca Vasco-Cantábrica. In: J.A.Vera (ed.), Geología de España, SGE-IGME, Madrid, 291-296. ISBN 84-7840-546-1
Gorostidi, A., Lamolda, M. (1991): El paso Cenomaniense-Turoniense de Menoyo (Alava): Variaciones de la nanoflora calcárea. Geogaceta $10,54-57$

Gräfe, K.-U. (1996): Sedimentary cycles in the Upper Cretaceous of the Basco-Cantabrian Basin (N. Spain) - an application of sequence stratigraphy. Mitteilungen aus dem Geologisch-Paläontologischen Institut der Universität Hamburg 77, 243-270.

Gräfe, K.-U., Wiedmann, J. (1993): Sequence stratigraphy in the Upper Cretaceous of the Basco-Cantabrian Basin (Northern Spain). Geologische Rundschau 82, 327-361.

Gräfe, K.-U., Wendler, J. (2003): Foraminifers and calcaroues dinoflagellate cysts as proxies for deciphering sequence stratigraphy, sealevel change and paleoceanography of Cenomanian-Turonian hemipelagic sediments in western Europe. In: H. C. Olson, R.M. Leckie (eds.), Micropaleontologic Proxies for Sea-level Change and Stratigraphic Discontinuities, SEPM Special Publication 75, 229-262, Tulsa. ISBN 1-56576-084-0

Haq, B. U., Hardenbol, J., Vail, P. R. (1987): Chronology of fluctuating sea levels since the Triassic. Science 235, 1156-1167.

Jarvis, I., Gale, A.S., Jenkyns, H.C., Pearce, M.A. (2006): Secular variation in Late Cretaceous carbon isotopes: A new carbonate reference curve for the Cenomanian-Campanian (99.6-70.6 Ma). Geological Magazine 143, 561-608. doi: 10.1017/S0016756806002421

Kennedy, W.J. (1984): Ammonite faunas and the "standard zones" of the Cenomanian to Maastrichtian Stages in their type areas, with some proposals for the definiton of the stage boundaries by ammonites. Bulletin of the Geological Society of Denmark 33, 147-161.

Kennedy, W. J., Jolkicev, N. A. (2004): Middle Cenomanian ammonites from the type section of the Sanandinovo Formation of Northern Bulgaria. Acta Geologica Polonica 54, (3) 369-380.

Kennedy, W. J., Walaszczyk, I., Cobban, W. A. (2000): Pueblo, Colorado, USA, candidate Global Boundary Stratotype Section and Point for the base of the Turonian Stage of the Cretaceous, and for the base of the Middle Turonian Substage, with revision of the Inoceramidae (Bivalvia). Acta Geologica Polonica 50 (3), 295-334.

Kossmat, F. (1897): Untersuchungen über die Südindische Kreideformation. Beiträge zur Paläontologie Österreich-Ungarns und des Orients 11, 1-46 (108-153).

Kuhnt, W., Holbourn, A., Gale, A., Chellai, E. H., Kennedy, W. J. (2009): Cenomanian sequence stratigraphy and sea-level fluctuations in the Tarfaya Basin (SW Morocco). Geological Society of America Bulletin 121 (11/12), 1695-1710. doi: 10.1130/B26418.1

Lamolda, M. A. (1979): Le Crétacé moyen de Menoyo (Ayala, Álava). Cuadernos de Geología Ibérica 5, 215-220.

Lamolda, M. A. (1998): An overview of the Cretaceous and Paleogene of the Basque-Cantabrian Basin. In: M. A. Lamolda (ed.), $24^{\circ}$ Coloquio Europeo de Micropaleontología (libro-guía), Bilbao, pp. 35-39.

Lamolda, M. A., Mathey, B., Rossy, M., Sigal, J. (1983): La edad del volcanismo cretácico de Vizcaya y Guipúzcoa. Estudios Geológicos 39, 151-155.

Lamolda, M.A., Peryt, D. (1998): The Cenomanian-Turonian boundary at the Menoyo section. In: M. A.Lamolda (ed.), $24^{\circ}$ Coloquio Europeo de Micropaleontología (libro-guía), Bilbao, pp. 53-56.

López-Horgue, M. A., Bodego, A. (2012): Ar-Ar and biostratigraphical dating of volcanism-related hydrothermalism: implications for fluidflow during the mid Cretaceous extensional episode in the BasqueCantabrian Basin. Proceedings of Geofluids International Conference, IFP Energies nouvelles, Rueil-Malmaison (France), June 6-8, 2012, pp. 209-211.

López-Horgue, M.A., Owen, H.G., Rodríguez-Lázaro, J., Orue-Etxebarria, X., Fernández-Mendiola, P.A., García-Mondéjar, J. (1999): Late Albian-Early Cenomanian stratigraphic succession near EstellaLizarra (Navarra, central northern Spain) and its regional and inter- 
regional correlation. Cretaceous Research 20, 369-402. doi: 10.1006/ cres. 1999.0162

López-Horgue, M. A., Iriarte, E., Schröder, S., Fernández-Mendiola, P. A., Caline, B., Corneyllie, H., Frémont, J., Sudrie, M., Zerti, S. (2010): Structurally controlled hydrothermal dolomites in Albian carbonates of the Asón valley, Basque-Cantabrian Basin, Northern Spain. Marine and Petroleum Geology 27, 1069-1092. doi: 10.1016/j.marpetgeo.2009.10.015

Lotze, F. (1960): Zur Gliederung der Oberkreide in der Baskischen Depression (Nordspanien). Neues Jahrbuch für Geologie und Paläontologie Monatshefte 1960, 132-144.

Maisey, J.G. (1991): Rhacolepis Agassiz, 1841. In: J. G. Maisey (ed.), Santana Fossils, an illustrated atlas. T. F. H. Publications, Neptune City, New Jersey, pp. 248-257.

Martínez, R., Lamolda, M., Gorostidi, A., López, G., Santamaría, R. (1996): Bioestratigrafía integrada del Cretácico Superior (Cenomaniense superior-Santoniense) de la Región Vasco-Cantábrica. Revista Española de Paleontología, número extraordinario, 160-171. ISSN 0213-6937

Mitchell, S. F., Paul, C. R. C., Gale, A. S. (1996): Carbon isotopes and sequence stratigraphy. In: J. Howell, J. F. Aitken (eds.), High resolution sequence stratigraphy: innovations and applications. Geological Society of London Special Publication 104, 11-24. doi:10.1144/GSL. SP.1996.104.01.02

Ogg, J. G., Agterberg, F.P. Gradstein, F.M. (2004): The Cretaceous period. In: F. M. Gradstein, J. G. Ogg, A. G. Smith (eds.), A Geologic Time Scale 2004, 344-383. Cambridge University Press, Cambridge. ISBN 9780521786737

Ogg, J. G., Hinnov, L. A. (2012): Cretaceous. In: F. M. Gradstein, J. G. Ogg, A.G. Smith (eds.), The Geologic Time Scale 2012. Volume 2, 793-853. Elsevier, Amsterdam. doi: 10.1016/B978-0-444-594259.01001-5

Poyato-Ariza, F.J. (2005): Pycnodont fishes: morphologic variation, ecomorphologic plasticity, and a new interpretation of their evolutionary history. Bulletin of the Kitakyushu Museum of Natural History and Human History, series A (Natural History) 3, 169-184.

Poyato-Ariza F. J., Martín-Abad, H. (2013): History of two lineages: comparative analysis of the fossil record in Amiiformes and Pycnodontiformes (Osteichthyes, Actinopterygii). Spanish Journal of Palaeontology 28 (1), 79-90.

Rat, P. (1959): Les pays crétacés basco-cantabriques (Espagne). Thèse Université Dijon (France) 18, 525 pp.

Robaszynski, F., Caron, M. (1995): Foraminifères planctoniques du Crétacé: Commentaire de la zonation Europe-Méditerranée. Bulletin de la Société Géologique de France 166, 681-692.

Robaszynski, F., Juignet, P., Gale, A. S., Amédro, F., Hardenbol, J. (1998): Sequence stratigraphy in the Cretaceous of the Anglo-Paris Basin, exemplified by the Cenomanian stage. In: T. Jaquin, P. de Graciansky, J. Hardenbol (eds.), Mesozoic and Cenozoic sequence stratigraphy of European basins. Soc. Econom. Palaeont. Mineral. Spec. Publ. 60, 363-385. Tulsa. ISBN 1-56576-043-3

Rodríguez-Lázaro, J., Pascual, A., Elorza, J. (1998): Cenomanian events in the deep western Basque Basin: the Leioa section. Cretaceous Research 19, 673-700. doi: 10.1006/cres.1998.0125

Rodríguez-Lázaro, J., Barroso-Barcenilla, F., Martín-Rubio, M. (2003): Análisis microfaunístico del Cenomaniense de Arceniega (Cuenca Navarro-Cántabra). Geogaceta 34, 115-118.

Saint-Seine, M. P. (1949): Les poissons des calcaires lithographiques de Cerin. Nouvelles Archives du Muséum d'Histoire Naturelle de Lyon
2, 1-357.

Santamaría, R. (1992): Los Ammonoideos del Cenomaniense superior al Santoniense de la plataforma nord-castellana y la cuenca navarrocántabra, parte I. Bioestratigrafía y sistemática: Phylloceratina, Ammonitina (Desmocerataceae y Hoplitaceae) y Ancyloceratina. Treballs del Museu de Geologia de Barcelona 2, 171-268.

Santamaría, R., López, G. (1996): Aspectos bioestratigráficos de los ammonites e inocerámidos (Bivalvia) del Albiense superior al Maastrichtiense de la provincia de Álava. Revista Española de Paleontología, número extraordinario 148-159. ISSN 0213-6937

Shimada, K., Fielitz, C. (2006): Annotated checklist of fossil fishes from the Smoky Hill Chalk of the Niobara Chalk (Upper Cretaceous) in Kansas. In: S. G. Lucas, R. M. Sullivan (eds.), Late Cretaceous vertebrates from the Western Interior. New Mexico Museum of Natural History and Science Bulletin 35, 193-213.

Taverne, L. (1989): Crossognathus PICTET, 1858 du Crétacé inférieur de l'Europe et Systématique, Paléozoogéographie et Biologie de Crossognathiformes nov. ord. (Téléostéens) du Crétacé et du Tertiaire. Palaeontographica Abt. A 207, 79-105.

Taverne, L. (2008): Les poisons crétacés de Nardò. 29 ${ }^{\circ}$ Nardopiscis cavini gen. et sp. nov. (Teleostei, Crossognathiformes, Pachyrhizodontidae). Bolletino del Museo Civico di Storia Naturale di Verona $32,19-28$.

Teller-Marshall, S., Bardack, D. (1978): The morphology and relationships of the Cretaceous teleost Apsopelix. Chicago Field Museum of Natural History, Fieldiana, Geology 41 (1), pp. 35.

Wiedmann, J. (1975): Subdivisiones y precisiones bio-estratigráficas en el Cretácico superior de las Cadenas Celtibéricas. In: B. Meléndez, F. Meléndez (eds.), Ier Symposium Cretácico Cordillera Ibérica, Cuenca 1974, Libro de actas, pp. 135-153.

Wiedmann, J. (1979): Itineraire geologique a travers le Cretace Moyen des Chaines Vascogotiques et Celtiberiques (Espagne du Nord), Mid Cretaceous Events-Iberian Field Conference 77. Cuadernos de Geología Ibérica 5, 127-214.

Wiedmann, J., Kauffman, G. (1978): Mid-Cretaceous biostratigraphy of northern Spain. Annales du Muséum d'Histoire Naturelle de Nice 4, III.1-III.34

Wiese, F., Wilmsen, M. (1999): Sequence stratigraphy in the Cenomanian to Campanian of the North Cantabrian Basin (Cantabria, NSpain). Neues Jahrbuch für Geologie und Paläontologie Abhandlungen, 212 (1-3) (J. Wiedmann Memorial Volume), 131-173, Stuttgart (E. Schweizerbart).

Wilmsen, M. (1997): Das Oberalb und Cenoman im Nordkantabrischen Becken (Provinz Kantabrien, Nordspanien): Faziesentwicklung, Biound Sequenzstratigraphie. Berliner Geowissenschaftliche Abhandlungen, Reihe E, Band 23, 167 pp. ISBN 3-89582-046-6

Wilmsen, M., Wiese, F., Ernst, G. (1996): Facies development, events and sedimentary sequences in the Albian to Maastrichtian of the Santander depositional area, northern Spain. Mitteilungen aus dem Geologisch-Paläontologischen Institut der Universität Hamburg 77, 337-367.

Wright, C.W., Kennedy, W.J. (1990): The ammonoidea of the Lower Chalk, Part 3. Monograph of the Palaeontographical Society, London, 219-294, pl. 56-86. (Publ. No. 585, part of Vol. 144 for 1990).

Wright, C.W., Calloman, J.H., Howarth, M.K. (1996): Cretaceous Ammonoidea, In: R.L. Kaesler (ed.), Treatise on Invertebrate Paleontology, Part L, Mollusca 4, revised, Volume 4. Geological Society of America (Boulder, Colorado) and The University of Kansas, Lawrence, Kansas. ISBN 0-8137-3112-7 
Appendix 1.- Ammonite and foraminifera species of biostratigraphic value in the study zone. Astobiza from Rat (1959). W-a to h from Wiedmann (1979), given with their original designation of this author. B from Barroso-Barcenilla et al. (2011). Ziorraga, Balmaseda and Ondiz sites are new localities with Late Albian ammonites under current study.

Ammonite associations (see figs. 2 and 3 for stratigraphical occurrences)

Astobiza (Altube area; Rat, 1959) (1 in fig. 2)

Stoliczkaia aff. dispar

S. aff. rhamnonota

S. gardonica

Ziorraga (Zi; Altube area) (2 in fig. 2; see also fig. 3)

Stoliczkaia sp.

Mariella sp.

Mortoniceras (Durnovarites) sp.

Balmaseda (near Ordunte) (3 in figure 2)

Stoliczkaia sp.

Ondiz (On; Leioa area) (see fig. 3)

Mortoniceras (Durnovarites) sp.

Cantabrigites sp.

Anisoceras sp.

Stoliczkaia sp.

Izoria (Amurrio area) (see figs. 2 and 3)

Calycoceras (Newboldiceras) asiaticum spinosum (KOSSMAT)

Villasana area (W-a to f; corresponding 10a to 10f of Wiedmann, 1979) (see figs. 2 and 3)

W-a (4 in fig. 2$)$

Graysonites sp.

Hypoturrilites mantelli (SHARPE)

$\mathbf{W}-\mathbf{b}$

Mantelliceras mantelli (J. SOW.)

M. menabense COLLIGNON

M. tuberculatum (MANTELL)

Tunesites $\mathrm{cf}$. latelobatum (COLLIGNON)

W-c

Forbesiceras largilliertianum (d'ORBIGNY)

Mantelliceras hyatti SPATH

M. costatum (MANTELL)

Calycoceras gr. newboldi (KOSSMAT)

W-d

Calycoceras newboldi (KOSSMAT)

C. subgentoni (SPATH)

W-e

Calycoceras gr. newboldi (KOSSMAT)

Calycoceras ef. choffati (KOSSMAT)

Eucalycoceras spathi COLLIGNON

E. pentagonum (JUKES-BROWNE)

W-f

rowei $(\mathrm{SPATH})$

Lotzeites lotzei WIEDMANN

Calycoceras newboldi spinosum (KOSSMAT)

C. newboldi madagascariense COLLIGNON

C. paucinodatum (CRICK)

Eucalycoceras gothicum (KOSSMAT)

Orbitolina (Mesorbitolina) aperta (ERMAN)

Orbitolina (Orbitolina) concava quatarica HENSON

Rotalipora appenninica (RENZ)

R. reicheli MORNOD

R. brotzeni (SIGAL)

$R$. greenhornensis (MORROW)

Praeglobotruncana stephani (GANDOLFI)

R. reicheli MORNOD

R. greenhornensis (MORROW)

Praeglobotruncana stephani (GANDOLFI)

Rotalipora cushmani (MORROW)

Hedbergella paradubia (SIGAL)

$R$, reicheli MORNOD

R. greenhornensis (MORROW)

Praeglobotruncana stephani (GANDOLFI)

Rotalipora cushmani (MORROW)

Praeglobotruncana turbinata (MORNOD)

R. globotruncanoides SIGAL

Rotalipora cushmani (MORROW)

Praeglobotruncana turbinata (MORNOD)

Cidad (W-g and h; both in locality 12 of Wiedmann, 1979) (see fig. 3)

W-g

Orbitolina (Conicorbitolina) conica (d'ARCHIAC)

Orbitolina (Orbitolina) concava quatarica HENSON

W-h

Orbitolina (O.) sefini HENSON sensu Gräfe, 1994)

Orbitolina (Conicorbitolina) conica (d'ARCHIAC)

Puentedey (B-a to d; corresponding beds of Barroso-Barcenilla et al., 2011) (see fig. 3)

B-a (bed 1 and lower part of bed 2)

Acanthoceras rhotomagense (BRONGNIART)

Calycoceras (C.) sp.

B-b (upper part of bed 2, bed 3 and bed 4)

Neolobites vibrayeanus (d'ORBIGNY)

Euomphaloceras euomphalum (SHARPE)

Calycoceras (C.) naviculare (MANTELL)

Metoicoceras mosbyense COBBAN

B-c (beds 5, 6 and 7)

M. geslinianum (d'ORBIGNY)

B-d (bed 8 and part of 9)

Spathites (Jeanrogericeras) subconciliatum (CHOFFAT)

Fagesia catinus (MANTELL)

Spathites (Jeanrogericeras) robustus (WIEDMANN)

Parapuzosia (Austiniceras) sp.

Vascoceras cauvini CHUDEAU 